\title{
Two Dimensional Hydrodynamic Analysis of the Moose Creek Floodway
}

Stephen H. Scott, Jeremy A. Sharp, Gaurav Savant,

September 2012

Crane Johnson, and Dee Ginter

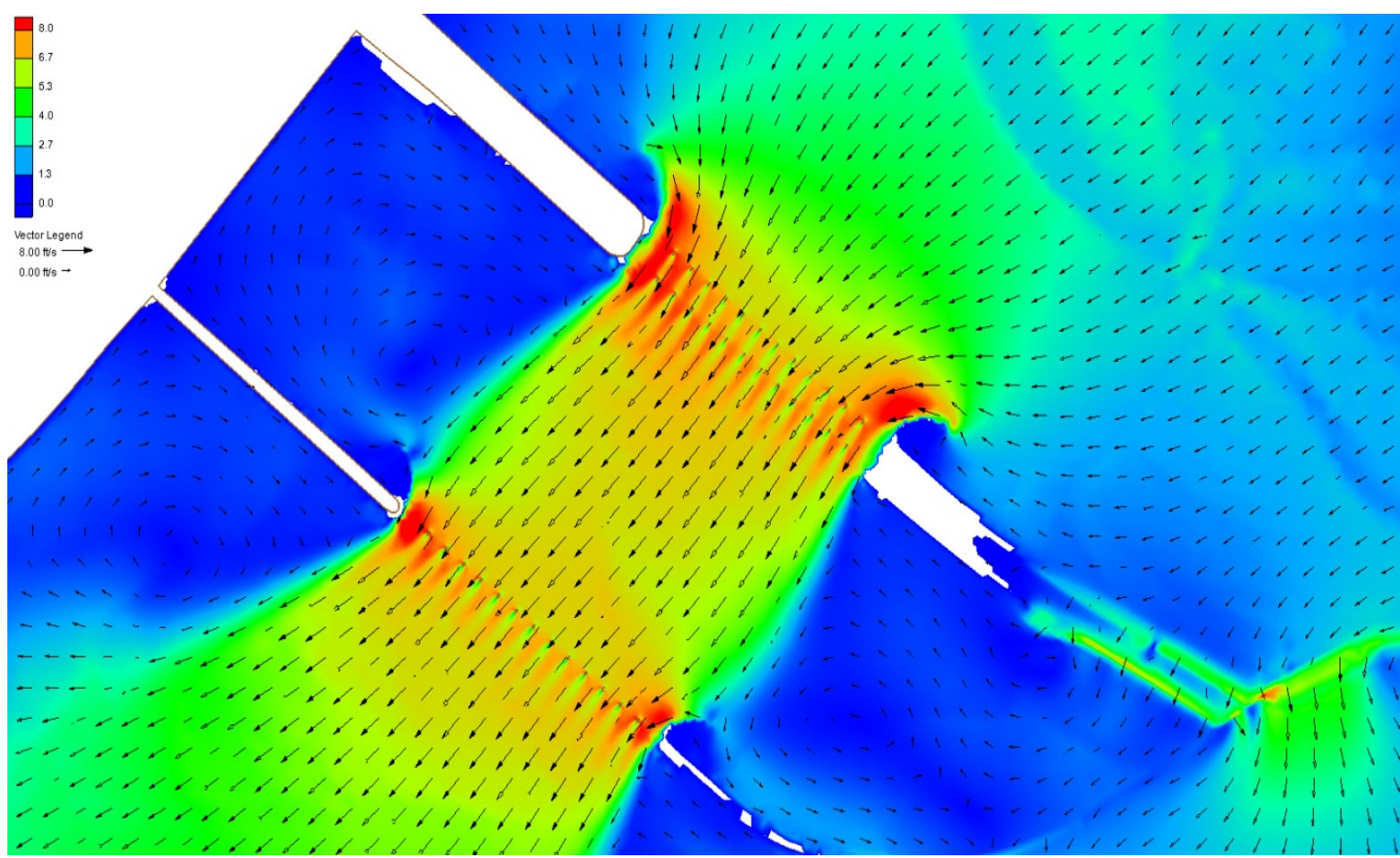




\section{Two Dimensional Hydrodynamic Analysis of the Moose Creek Floodway}

Stephen H. Scott, Jeremy A. Sharp, and Gaurav Savant

Coastal and Hydraulics Laboratory

U.S. Army Engineer Research and Development Center

3909 Halls Ferry Rd

Vicksburg, MS 39180

Crane Johnson and Dee Ginter

U.S. Army Corp of Engineer Alaska District

$22043^{\text {rd }}$ Street

JBER, AK 99506-0898

Final report

Approved for public release; distribution is unlimited.

Prepared for U.S. Army Corps of Engineers Alaska District Anchorage, AK 


\section{Abstract}

A two-dimensional Adaptive Hydraulics (AdH) hydrodynamic model was developed to simulate the Moose Creek Floodway. The Floodway is located approximately 17 miles East of Fairbanks, Alaska, and is part of the Chena River Lakes Flood Control project. The Chena River floodway is designed to reduce the flood risk at Fairbanks, AK by re-routing flood flows into the Tanana River. The floodway control sill is designed to prevent backwater from the Tanana River from entering the floodway. A dam to the west and high ground to the east contain the flow in the floodway connecting the Chena River to the Tanana River. Controlling factors for the head on the dam are; floodway channel surface roughness, channel constrictions due to the highway and railroad bridge crossings, and the elevation of the downstream control sill. The effort completed three tasks. The first developed a two-dimensional floodway model to be efficiently executed on a personal computer. The second task investigated the impact of highway and railroad bridge piers on floodway water surface profiles during flood conditions using the High Performance Computer (HPC). Finally, the model was optimized to predict impacts of changes to floodway vegetation and Tanana River stage on backwater profiles and was applied to evaluate backwater profiles for the probable maximum flood.

DISCLAIMER: The contents of this report are not to be used for advertising, publication, or promotional purposes. Citation of trade names does not constitute an official endorsement or approval of the use of such commercial products. All product names and trademarks cited are the property of their respective owners. The findings of this report are not to be construed as an official Department of the Army position unless so designated by other authorized documents. 


\section{Contents}

Abstract........................................................................................................................................... ii

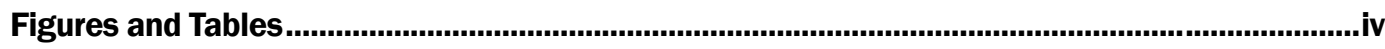

Preface ...............................................................................................................................................vi

Unit Conversion Factors.......................................................................................................vii

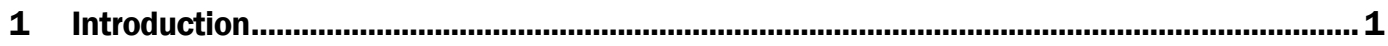

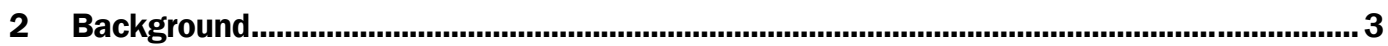

3 PC Based Model Development and Simulation ...................................................................... 5

3.1 Model description ............................................................................................. 5

3.2 Model simulations - PMF flood event ............................................................. 5

3.2.1 PMF simulation with pre-2010 sill (elevation of 511.65 NAVD 88)........................... 7

3.2.2 PMF simulation with Post-2010 condition (no sill)..................................................10

3.2.3 PMF simulation with post-2010 + diversion overflow weir..................................... 10

4 Impact of Bridge Piers and Upstream Model Boundary Storage on Floodway Hydrodynamics .......................................................................................................................16

4.1 HPC bridge pier/model boundary simulation results - PMF flood event................ 17

5 Alaska District Model Modifications.........................................................................................19

5.1 Description of submerged vegetation roughness option in $\mathrm{AdH}$............................. 19

5.2 Description of un-submerged vegetative roughness in $\mathrm{AdH}$.................................20

5.3 Final mesh HPC model simulation - PMF flood event .......................................... 21

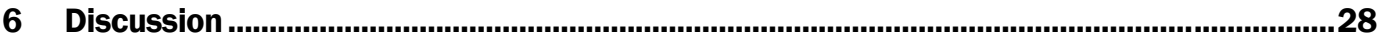

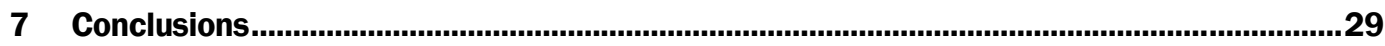

References.............................................................................................................................................30

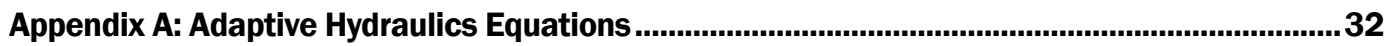

Appendix B: Submerged Aquatic Vegetation Roughness Calculations .......................................35

\section{Report Documentation Page}




\section{Figures and Tables}

\section{Figures}

Figure 1. Chena River Lakes Project

Figure 2 Base Moose Creek Dam Floodway model ........................................................................... 6

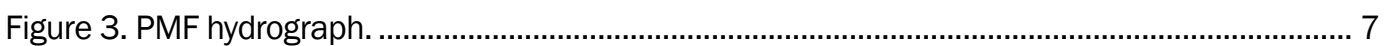

Figure 4. Maximum water depth for the PMF event - Pre-2010...................................................... 8

Figure 5. Maximum velocity for the PMF event - Pre-2010 .......................................................... 8

Figure 6. Maximum flow velocity and direction for the PMF event - Pre-2010 ................................. 9

Figure 7. Longitudinal water surface profile at the peak of the PMF event - sill at raised elevation

Figure 8. Flow vector comparison between the numerical model $(\mathrm{AdH})$ in orange and the physical model in black during peak discharge through the bridges within the floodway................. 10

Figure 9. Maximum water depth for the PMF event - Post-2010 ................................................... 11

Figure 10. Maximum velocity for the PMF event - Post-2010......................................................... 11

Figure 11. Maximum flow velocity and direction for the PMF event - Post-2010........................... 12

Figure 12. Longitudinal water surface profile at the peak of the PMF event - post-2010............... 12

Figure 13. Base floodway mesh with overflow weir - Post-2010 + diversion overflow weir.............. 13

Figure 14. Maximum depth for the PMF event - Post-2010 + diversion overflow weir. ................... 13

Figure 15. Maximum velocity for the PMF event - Post-2010 + diversion overflow weir.................. 14

Figure 16. Maximum flow velocity and direction for the PMF event - Post-2010 +

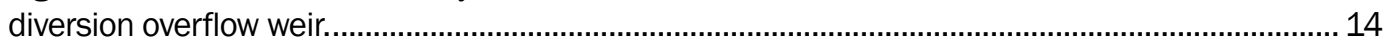

Figure 17. Longitudinal water surface profile at the peak of the PMF event - Post-2010 + diversion overflow weir........................................................................................................... 15

Figure 18. Location and orientation of bridge piers in the numerical mesh.................................... 16

Figure 19. Base mesh extents (left side) compared to extended mesh extents (right side). ........... 17

Figure 20. Comparison of water surface profile elevation with and without piers. ........................... 18

Figure 21. Comparison of water surface profiles for the full mesh (base condition) and extended mesh.

Figure 22. Impact of water depth over submerged vegetation on roughness. ................................ 20

Figure 23. Roughness as a function of relative stem density....................................................... 21

Figure 24. Final floodway mesh with Tanana River segment............................................................2

Figure 25. Photograph of a typical section of maintained floodway on the left and an area

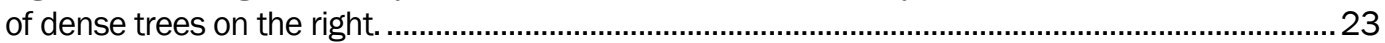

Figure 26. Final floodway bed roughness map used in the Alaska District PMF simulation............ 24

Figure 27. Maximum depth for the PMF event - Post-2010 + diversion overflow weir + Tanana River.

Figure 28. Maximum velocity for the PMF event - Post-2010 + diversion overflow weir + Tanana River 
Figure 29. Maximum flow velocity and direction for the PMF event - Post-2010 + diversion overflow weir + Tanana River.

Figure 30. Water surface elevation profile at the peak of the PMF event - Post-2010 + diversion overflow weir + Tanana River.

Figure 31. Comparison of simulated water surface profiles with the Moose Creek Dam crest elevation profile.

\section{Tables}

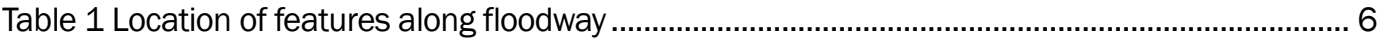

Table 2. Final roughness designations in the final AdH model........................................................ 23 


\section{Preface}

This study was conducted for the US Army Corps of Engineers Alaska District.

The work was performed by the River Engineering Branch (CEERD-HF-R) of the Flood and Strom Protection Division (HF), U.S. Army Engineer Research and Development Center - Coastal and Hydraulics Laboratory (ERDC-CHL). At the time of publication, Jose E. Sanchez was Chief, River Engineering Branch; Ty Wamsley was Chief, Flood Storm and Protection Division; and Bill Curtis was the Technical Director for Flood and Coastal Storm Damage Reduction. The Deputy Director was Mr. Jose E. Sanchez and the Director was Dr. William Martin.

COL Kevin J. Wilson was the Commander and Executive Director of ERDC, and Dr. Jeffery P. Holland was the Director. 


\section{Unit Conversion Factors}

\begin{tabular}{|l|c|l|}
\hline Multiply & By & To Obtain \\
\hline acres & $4,046.873$ & square meters \\
\hline cubic feet & 0.02831685 & cubic meters \\
\hline feet & 0.3048 & meters \\
\hline inches & 0.0254 & meters \\
\hline miles (U.S. statute) & $1,609.347$ & meters \\
\hline
\end{tabular}




\section{Introduction}

This report summarizes work performed by both the Engineering Research and Development Center (ERDC) and the Alaska District Corps of Engineers (CEPOA). The purpose of this report is to document the development of a two-dimensional hydrodynamic model that can be applied to simulate the hydrodynamics of the Moose Creek Floodway located approximately 17 miles East of Fairbanks Alaska. The floodway is part of the Chena River Lakes Flood Control project (Figure 1) which was authorized by the Flood Control Act of 13 August 1968, Public Law 90-483, Section 203, 90 ${ }^{\text {th }}$ Congress (S-3710). The project consists of three main features; the Moose Creek earthen dam which regulates Chena River flows through downstream Fairbanks, a floodway for re-directing excessive flood flows to the Tanana River, and a levee system along the Tanana River.

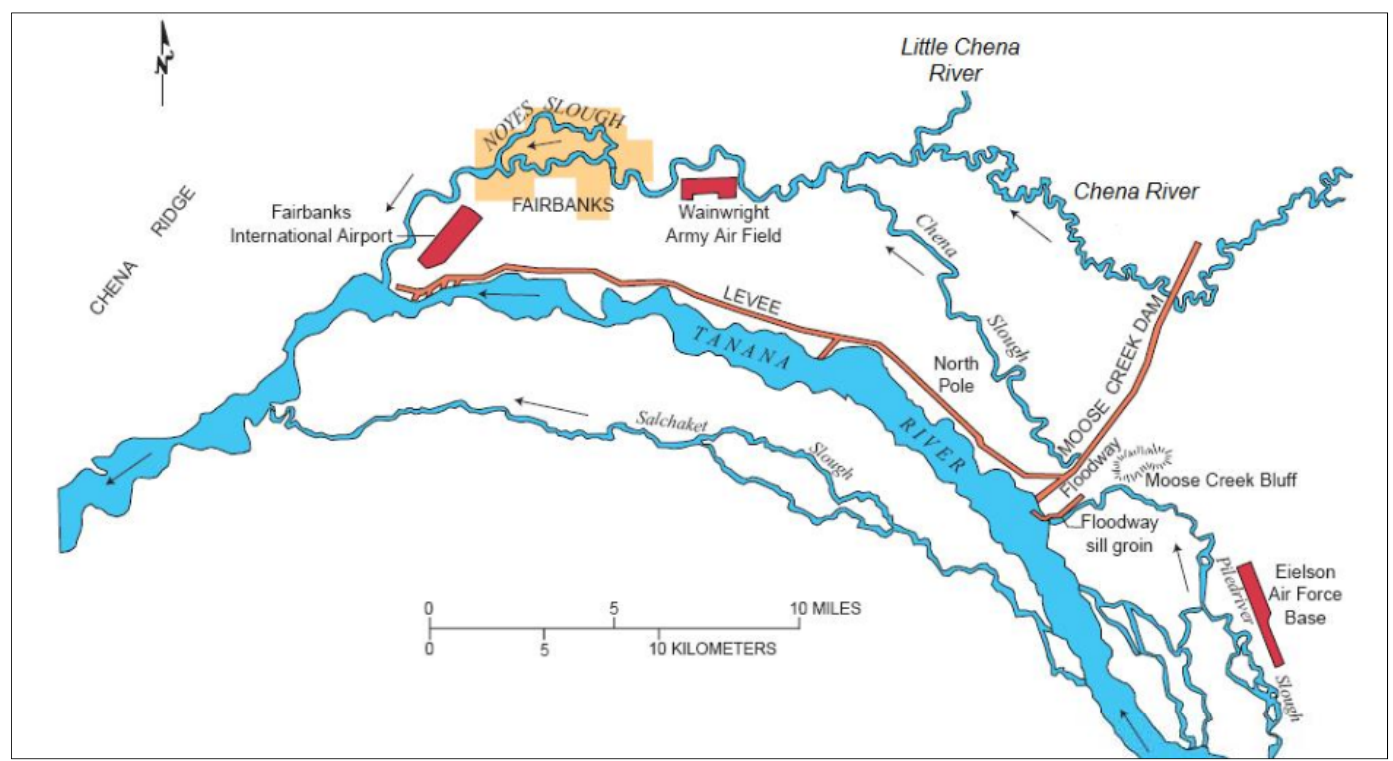

Figure 1. Chena River Lakes Project.

The hydrodynamics model applied for the study, Adaptive Hydraulics (AdH), was developed at the ERDC. The AdH Model is a software package that can describe both saturated and unsaturated groundwater, overland flow, 3-D Navier-Stokes, and 3-D Shallow Water problems in addition to 2-D shallow water problems (Berger et al. 2010). It can be used in a serial or multiprocessor mode on personal computers, UNIX, McIntosh Computers as well as High Performance Computing systems. A uniqueness of AdH is its ability to dynamically refine the domain mesh in areas where more 
resolution is needed at certain times due to changes in the flow or transported constituent conditions. AdH can simulate the transport of conservative constituents, as well as sediment transport that is coupled to bed and hydrodynamic changes. The sediment transport computations are computed in the sediment library of AdH (SEDlib). The ability of AdH to allow the domain to wet and dry as flow conditions or tides change is suitable for shallow marsh environments, beach slopes, floodplains, and the like. AdH is set up such that supercritical and subcritical flows can be represented at the model boundaries as well as internal to the system. It has the capability to simulate vessel transport as well as bridge decks and culvert entrances as pressure field applications. The model is being developed at the Coastal and Hydraulics Laboratory (CHL) and has been applied to model hydrodynamics in sections of the Mississippi River, tidal conditions in southern California, and vessel traffic in the Houston Ship Channel among others (Stockstill and Vaughan, 2009; Stockstill et al. 2010; Martin et al. 2011; Tate et al. 2010). The model is designed to work in conjunction with the DoD Groundwater Modeling System (GMS). The GMS and the Surface Water Modeling System (SMS) are modeling packages for building models, running simulations, and visualizing results.

The modeling effort consisted of three main goals.

- Develop a two-dimensional floodway model that could be efficiently executed on a personal computer (PC).

- Investigate the impact of highway and railroad bridge piers on floodway water surface profiles during flood conditions,

- Optimize the model for predicting impacts of floodway vegetation and Tanana River stage on backwater profiles.

The ERDC completed the first two goals of the study, while CEPOA, District, engineers developed a detailed vegetation roughness map of the floodway and added a segment of the Tanana River to the model. The final optimized model was applied to evaluate backwater profiles for the probable maximum flood (PMF). Variations in the final model geometry were also used to evaluate potential dam modification alternatives that could impact the hydrodynamics of the floodway. 


\section{Background}

The Chena River floodway is designed to reduce the flood risk at Fairbanks by re-routing flood flows through the floodway into the Tanana River. When the Chena River discharge through downtown Fairbanks is expected to exceed 12,000 cfs, the control works gates are closed and water is diverted into the floodway. The water flows parallel to Moose Creek dam 6.7 miles to the floodway control sill adjacent to the Tanana River. The floodway control sill is designed to prevent backwater from the Tanana River from entering the floodway. The sill was constructed to an elevation of 511.75 NAVD88, which is approximately 4.65 feet above the ground elevation at the sill. In 2010, the sill was lowered to an elevation of 507.00 feet NAVD88 allowing water to flow into the Tanana River sooner thus creating a lower backwater profile.

A number of modeling studies were conducted to evaluate the initial floodway design, the impacts of vegetation on floodway elevation, and the impact of changing the floodway control sill elevation. A physical model study of the floodway was conducted by the North Pacific Division of the Corps of Engineers to evaluate system hydraulics and bridge scour potential (North Pacific Division Technical Report 1984). In 1987 a value engineering study was conducted by the Alaska District to evaluate the cost of clearing the floodway to reduce hydraulic roughness (Alaska District 1987). Two models were used to analyze the floodway, a one-dimensional model HEC-2 developed by the Corps of Engineers Hydrologic Engineering Center, and a two-dimensional model RMA2 developed by the ERDC. Various channel roughness scenarios were analyzed for a number of floodway vegetation clearing options, with the Manning's $n$ roughness ranging from 0.02 in the cleared excavated areas to 0.15 in the wooded areas. The results of the study indicated that the floodway clearing limits could be reduced by 740 acres without encroaching on the dam freeboard limitation of 4.0 feet.

Moose Creek dam is an earth filled dam that is designed to contain relatively short duration floods. As with other earthen dams, it is subject to stability issues such as seepage and piping flows due to the hydraulic gradient across the dam during flooding. To reduce the potential for dam failure during flooding, the optimal floodway design condition is to reduce the water surface elevation along the dam. The water surface controls for 
the floodway are primarily floodway channel surface roughness, channel constrictions due to the highway and railroad bridge crossings, and the elevation of the downstream control sill. The control sill crest elevation was sited to prevent Tanana River floodwater from entering the floodway. However, the sill elevation ( 4.65 feet above the ground elevation) increases the backwater elevation along the dam during flood, thus potentially impacting dam stability. To address this concern, a detailed numerical model study was conducted by the Alaska District to evaluate the impact of removing the sill on the water surface profile along Moose Creek dam (Alaska District 2010). Based on this study, it was recommended that the sill be removed to ground level (507.00 feet NAVD88). The sill was removed to ground level in April 2010 to reduce both the maximum pool elevation and duration. The sill configuration as originally constructed will be referred to as 'pre-2010' and the modified sill configuration will be referred to as 'post-2010'. 


\section{PC Based Model Development and Simulation}

The goal of the PC based two-dimensional model was to develop a representative model that could be executed on a single processor $\mathrm{PC}$ with a reasonable simulation time of less than four hours. It provided the sponsor a tool that is changed easily to provide rapid response. To accomplish this, the model resolution (number of computational nodes and elements) were minimized. Resolution was added in areas to capture essential features or bathymetry, or to resolve the model when the hydrodynamics (velocity and change in water surface) was highly dynamic. Areas of the model domain that are not dynamic or serve mainly as storage are assigned fewer nodes and elements. The vertical datum for all the model results presented in this report is in NAVD 88.

\subsection{Model description}

The Moose Creek Floodway model was digitized from area bathymetry data provided by the Alaska District. The horizontal projection system used for this modeling effort is State Plane NAD 83 U.S. survey feet. The essential features in the model include a segment of the Chena River (inflow boundary), an outflow discharge boundary at the Chena River control structure, Moose Creek Dam, highway and railroad bridge openings, the downstream floodway control sill, and a representative Tanana River downstream stage boundary (Figure 2). Table 1 provides the distance of pertinent floodway features from the lower floodway control sill. The maximum flood plain elevation in the model was approximately 525 feet, NAVD 88. A grid convergence test was conducted to determine the minimum model resolution required to insure model stability, reasonable simulation times, and convergent results. The final model resolution for the PC based floodway mesh was determined to be 14,540 elements and 7,547 nodes. For the following simulations, a global Manning's roughness value of 0.03 , the average representative roughness, was used in the model. The global roughness was necessary since the variations in roughness could not be defined appropriately due to the lower resolution of the PC model.

\subsection{Model simulations - PMF flood event}

The model simulations were conducted to evaluate the worst case flood risk along the floodway. This was best represented by the probable 


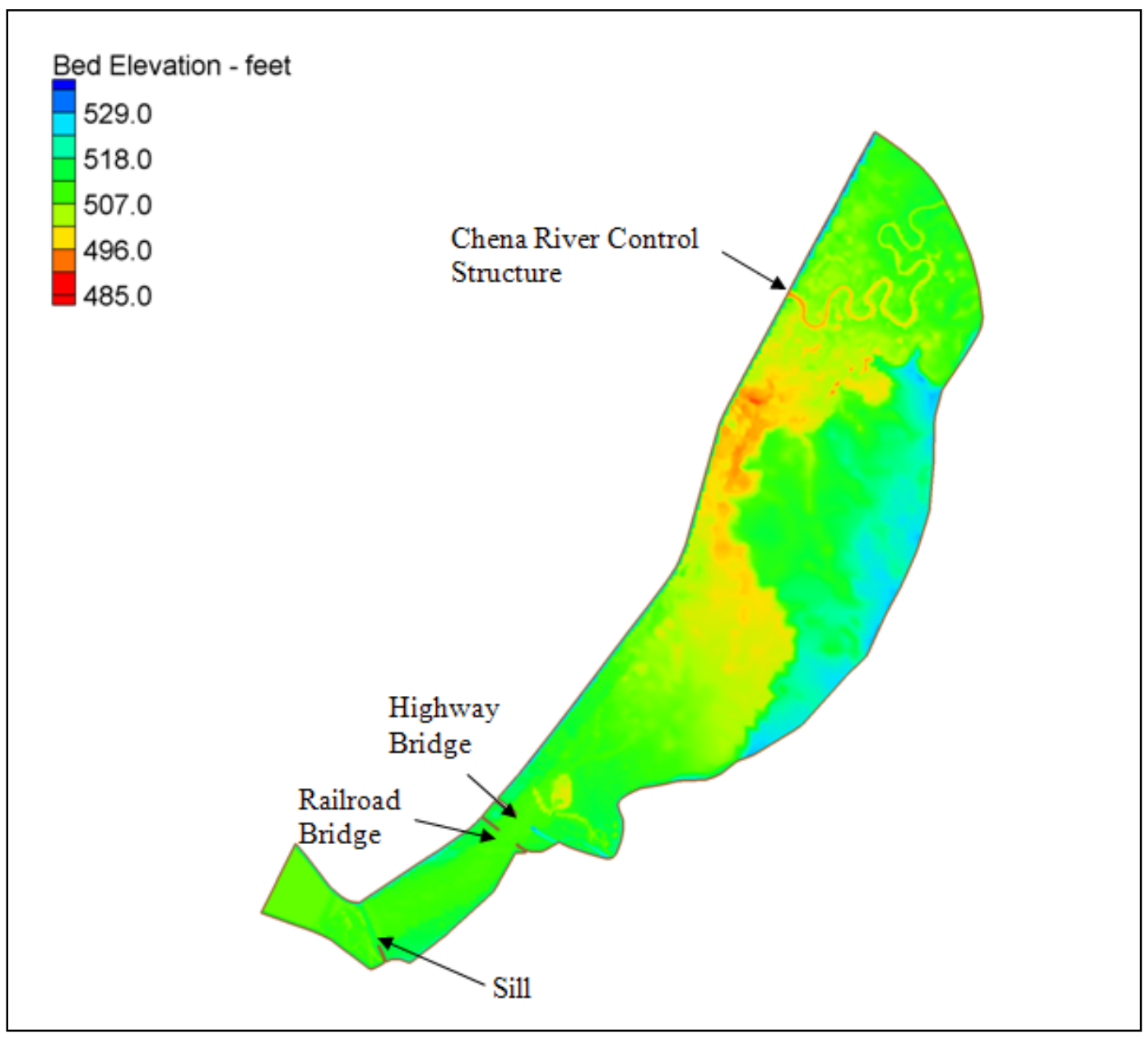

Figure 2 Base Moose Creek Dam Floodway model

Table 1 Location of features along floodway

\begin{tabular}{|l|l|}
\hline Location & $\begin{array}{l}\text { Distance From Downstream } \\
\text { Control Sill - feet }\end{array}$ \\
\hline Railroad Bridge (AKRR) & 7676 \\
\hline Highway Bridge & 8691 \\
\hline Chena River CS & 36491 \\
\hline
\end{tabular}

maximum flood (PMF) for the Chena River. The original PMF project inflow hydrograph, shown in the water control manual, was provided to ERDC (Figure 3). The hydrograph has a peak flow of 186,000 cfs, with a duration of approximately 5.5 days. The model's downstream water level was represented by the Tanana River stage (a constant value of 510 feet NAVD 88 was used for all simulations). Three simulations are presented for the PMF hydrograph; 
- Pre-2010 conditions (sill)

- Post-2010 conditions (no sill)

- Post-2010 conditions + diversion overflow weir (diversion overflow weir added to account for highway overtopping during the peak of the flood)

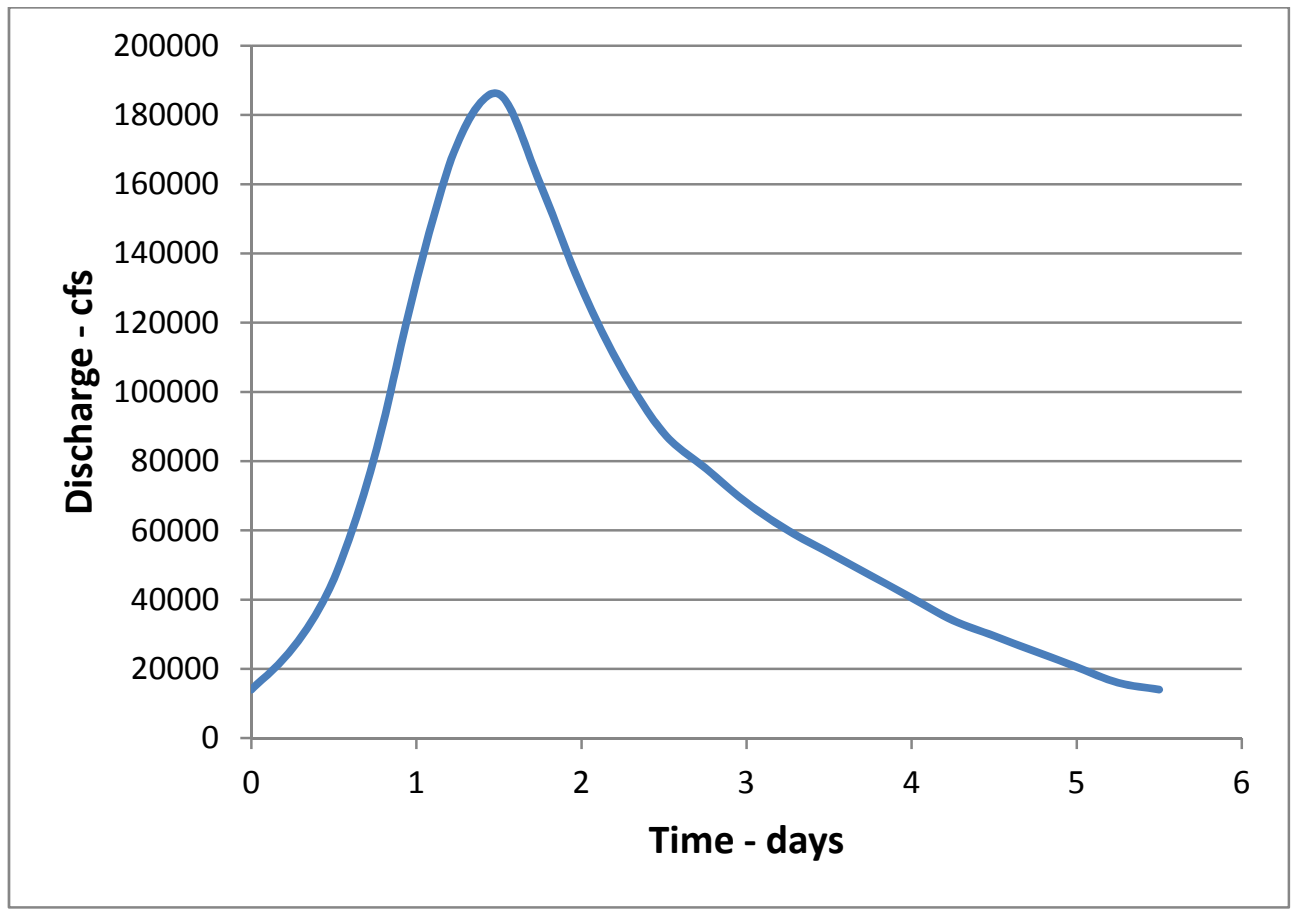

Figure 3. PMF hydrograph.

\subsubsection{PMF simulation with pre-2010 sill (elevation of 511.65 NAVD 88)}

For this simulation, the bed elevation at the sill location was raised to 511.65 feet ( $4.65 \mathrm{ft}$ above ground elevation). The maximum depth and velocity contours across the domain are found in Figures 4 and 5, with velocity magnitude and direction contours between the bridge openings shown in Figure 6. This simulation was used as a validation measure to compare the current numerical model with results from the previous physical model. Generally, the velocity between the bridge openings agreed with the physical model study conducted by the North Pacific Division (8-9 $\mathrm{ft} / \mathrm{sec})$. Figure 7 shows the raised water surface elevation profile. Figure 8 shows a comparison of the physical model flow vectors and the numerical simulation flow vectors during peak flow through the highway bridges. Eddies adjacent to the highway and railroad bridges generally agree in size, shape and location between the models, however the magnitudes are different. 


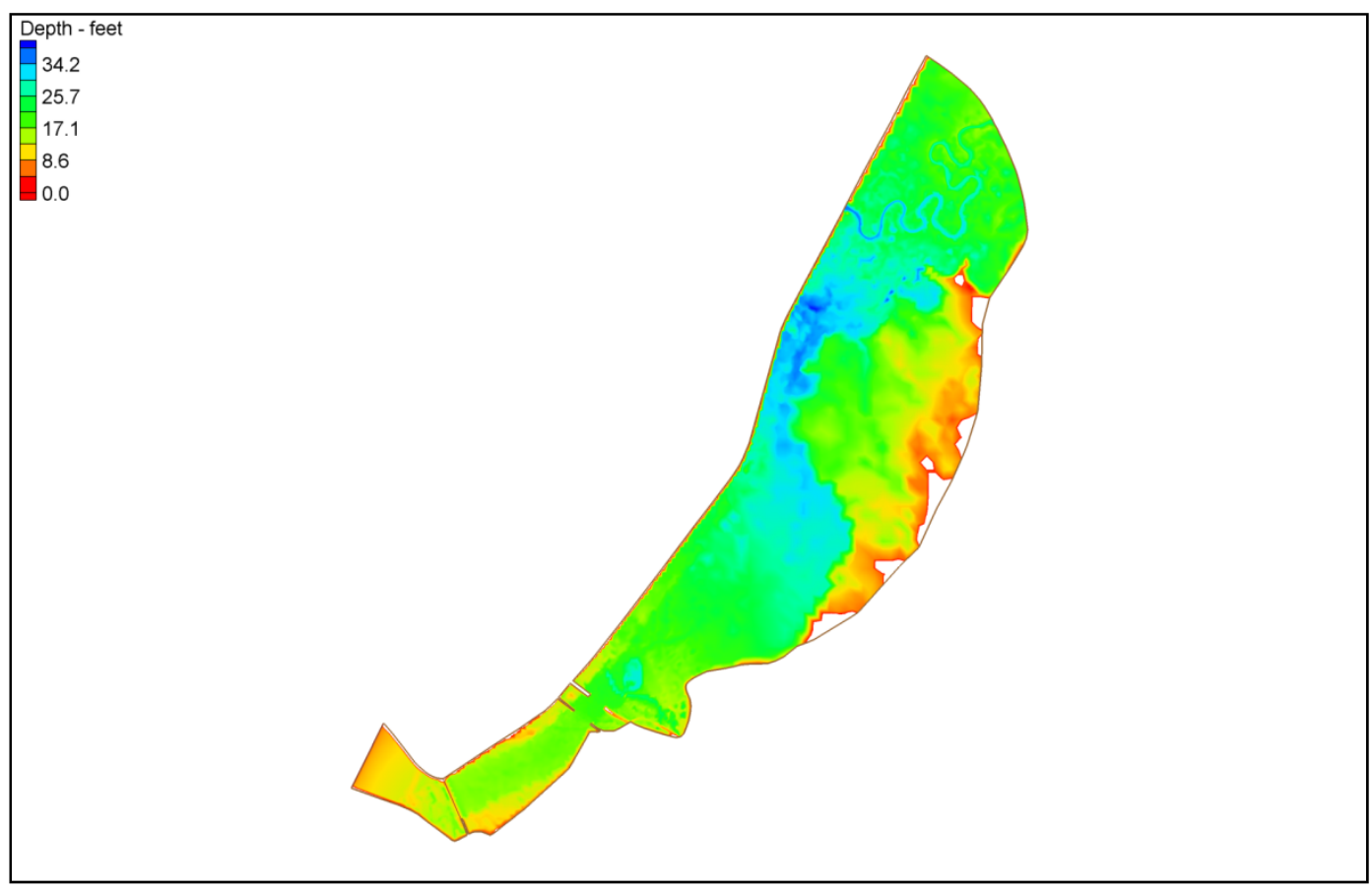

Figure 4. Maximum water depth for the PMF event - Pre-2010.

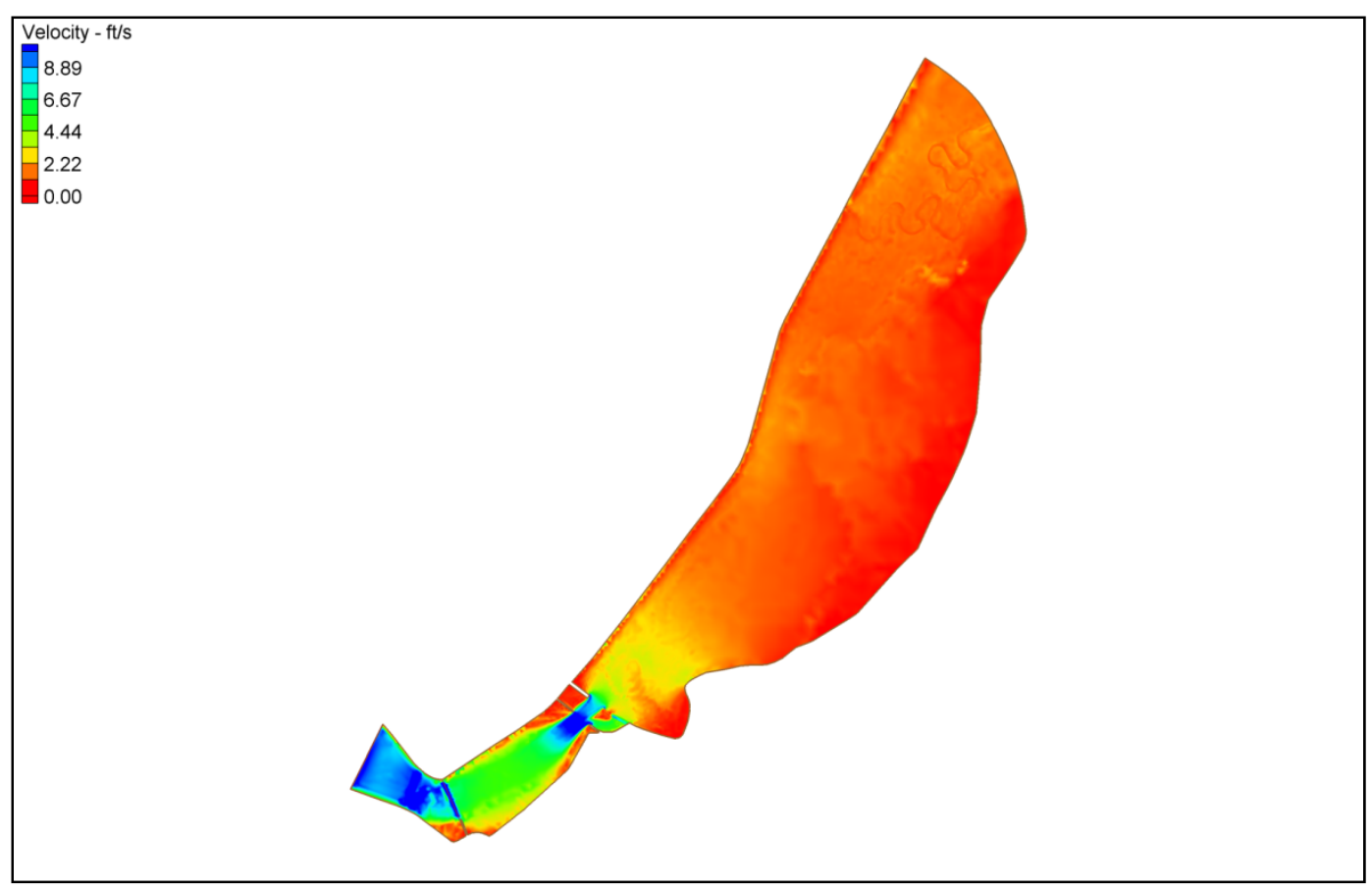

Figure 5. Maximum velocity for the PMF event - Pre-2010. 


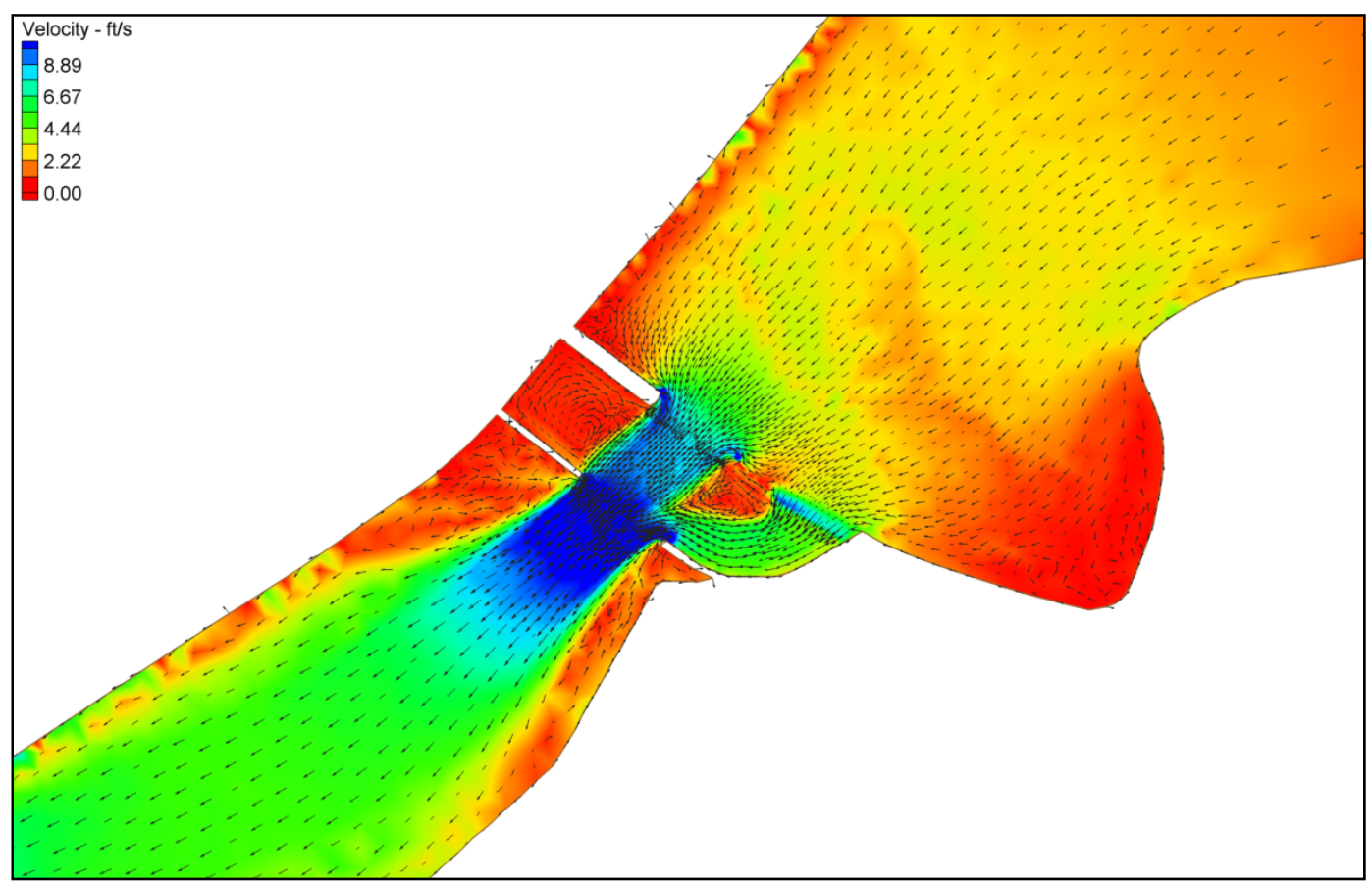

Figure 6. Maximum flow velocity and direction for the PMF event - Pre-2010.

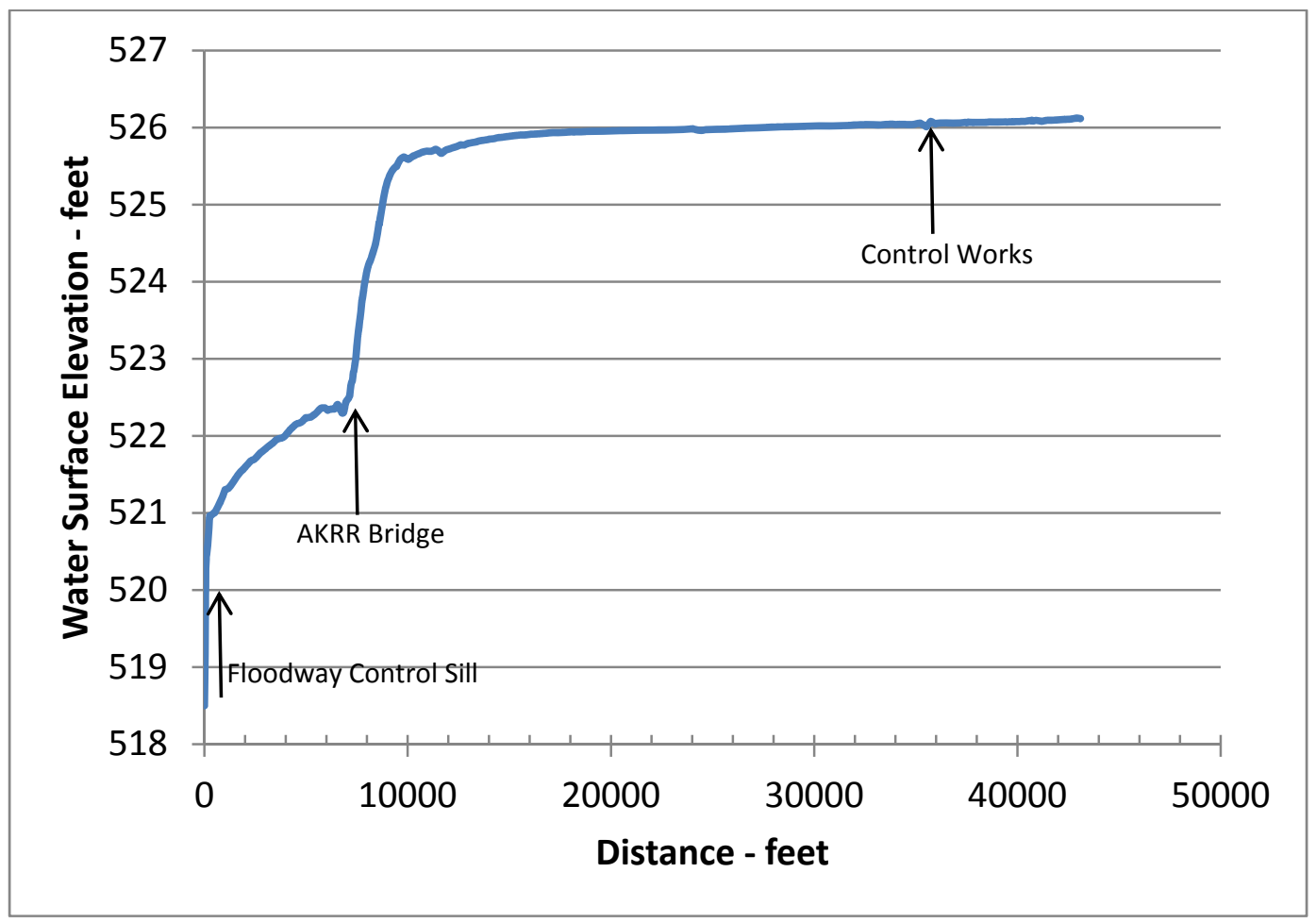

Figure 7. Longitudinal water surface profile at the peak of the PMF event - sill at raised elevation (pre-2010). 


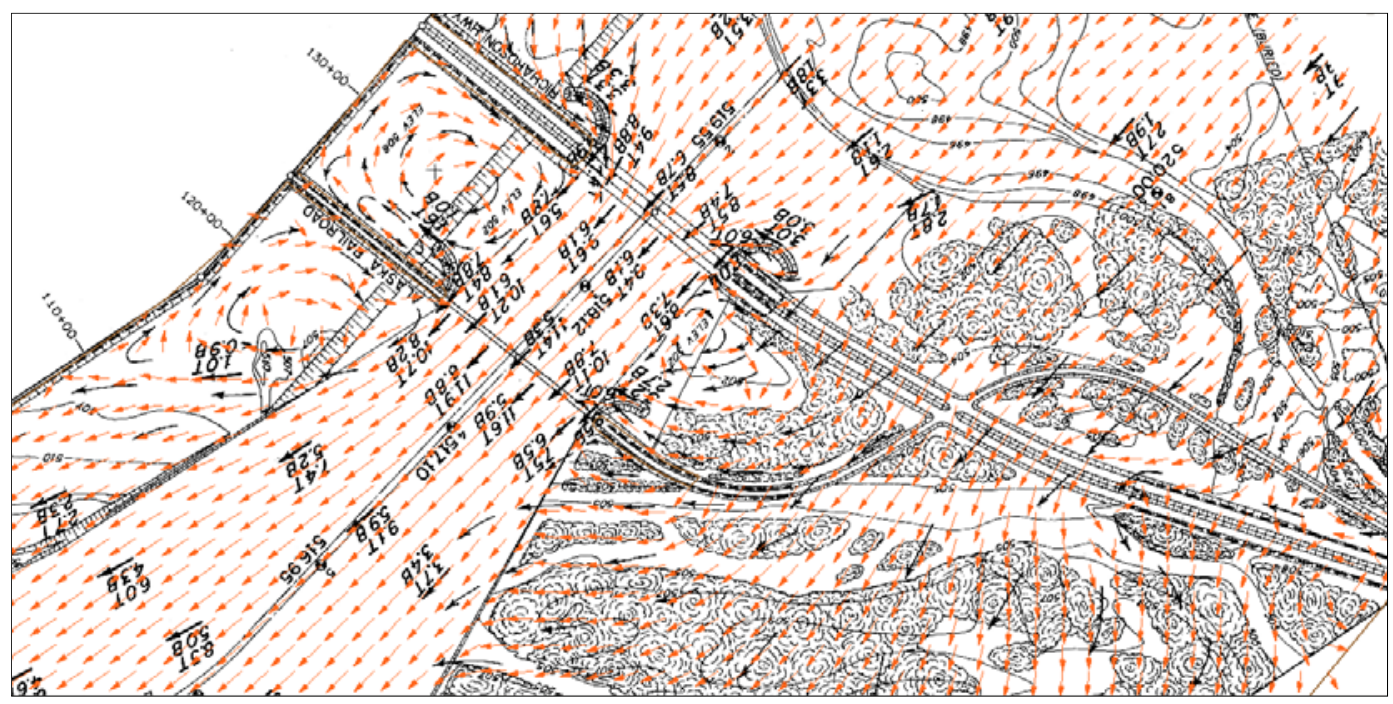

Figure 8. Flow vector comparison between the numerical model (AdH) in orange and the physical model in black during peak discharge through the bridges within the floodway (Pre2010 vs. Physical Model).

\subsubsection{PMF simulation with Post-2010 condition (no sill)}

The maximum depth and velocity contours across the domain are found in Figures 9 and 10. The velocity magnitude and direction contours between the bridge openings are shown in Figure 11. The maximum longitudinal water surface profile along the model domain is presented in Figure 12. The maximum water surface elevation at the Chena River control structure was approximately 524.9 feet NAVD 88 . The peak discharge through the lower floodway below the bridge openings was $164,000 \mathrm{cfs}$. The simulation results indicate that the presence of the sill results in approximately a one foot increase in water surface elevation over the domain.

\subsubsection{PMF simulation with post-2010 + diversion overflow weir}

The initial simulations indicated that the Eastern section of the highway bridge overtops during the peak of the PMF. Previous hydraulic studies of the Floodway did not account for this overtopping flow that is diverted away from the floodway into the Tanana River floodplain. To account for this diverted flow, a new model mesh was created with a diversion weir to remove the peak flood flows that overtop the roadbed (Figure 13). The simulation results are presented in Figures $14-17$. The results indicate that approximately 16 percent of the peak flow passes through the diversion weir. The water surface elevation at the Chena River control structure is reduced by approximately 0.5 feet when compared to the Post2010 model (no diversion weir simulation). 


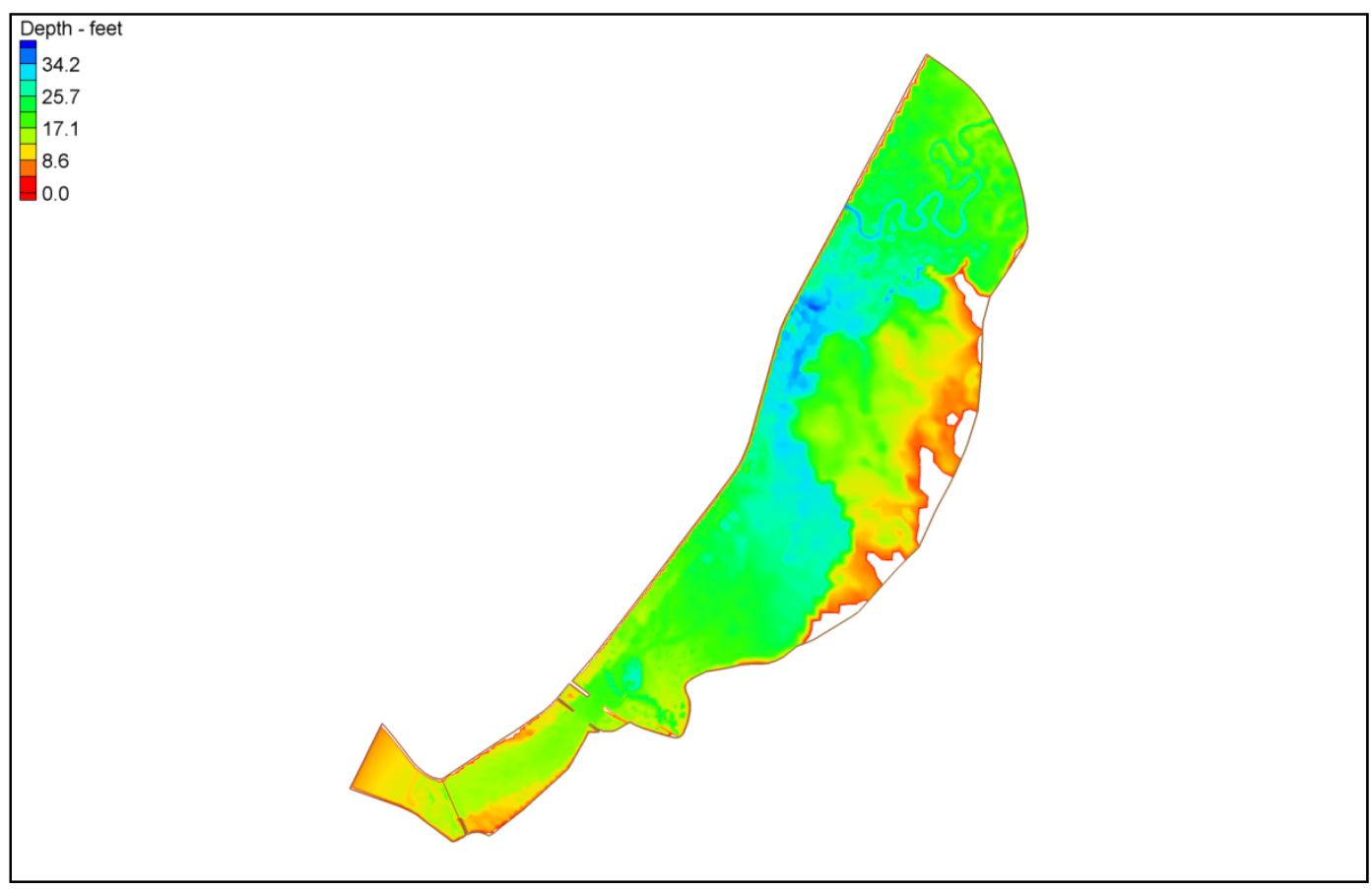

Figure 9. Maximum water depth for the PMF event - Post-2010.

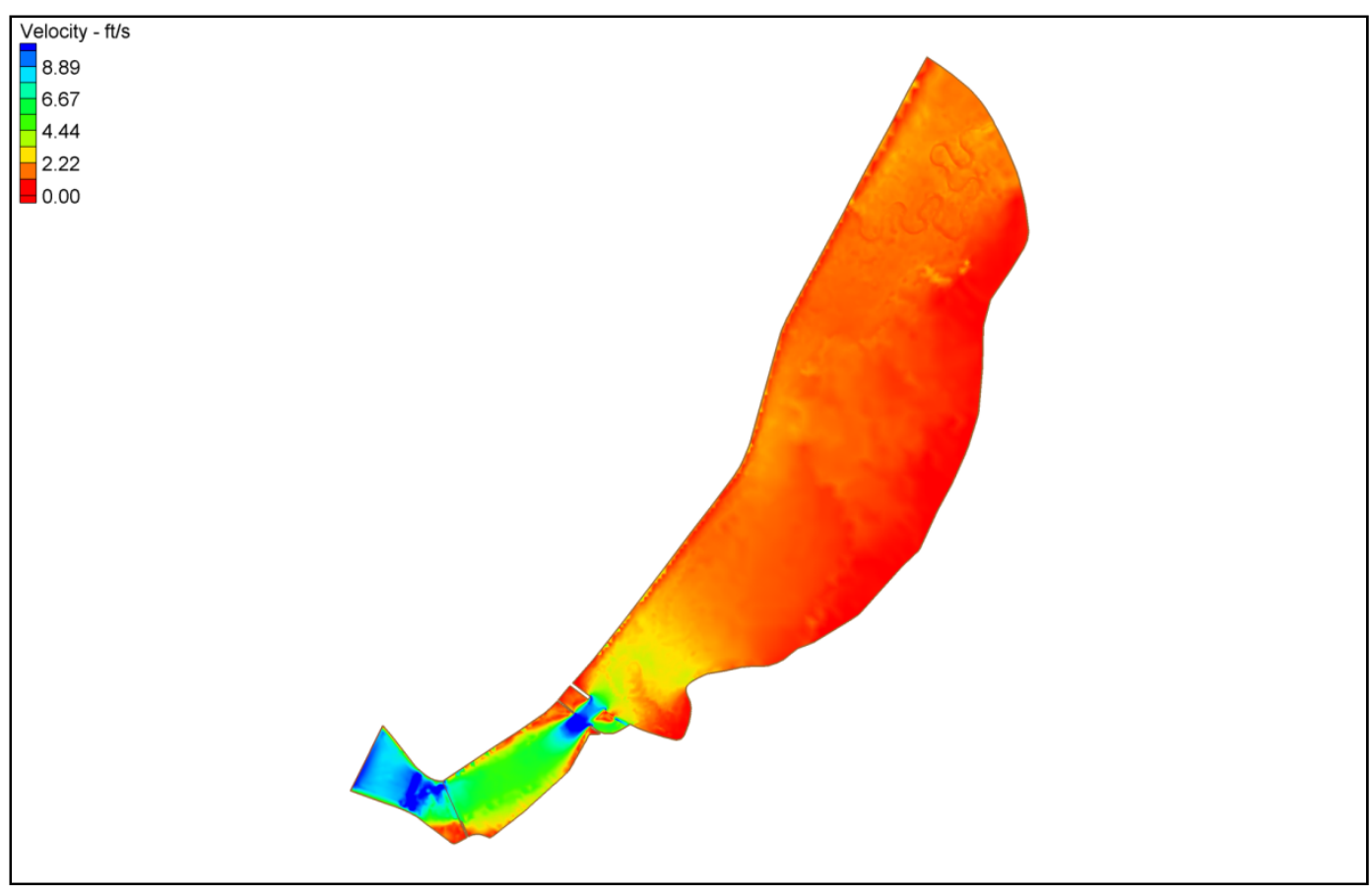

Figure 10. Maximum velocity for the PMF event - Post-2010. 


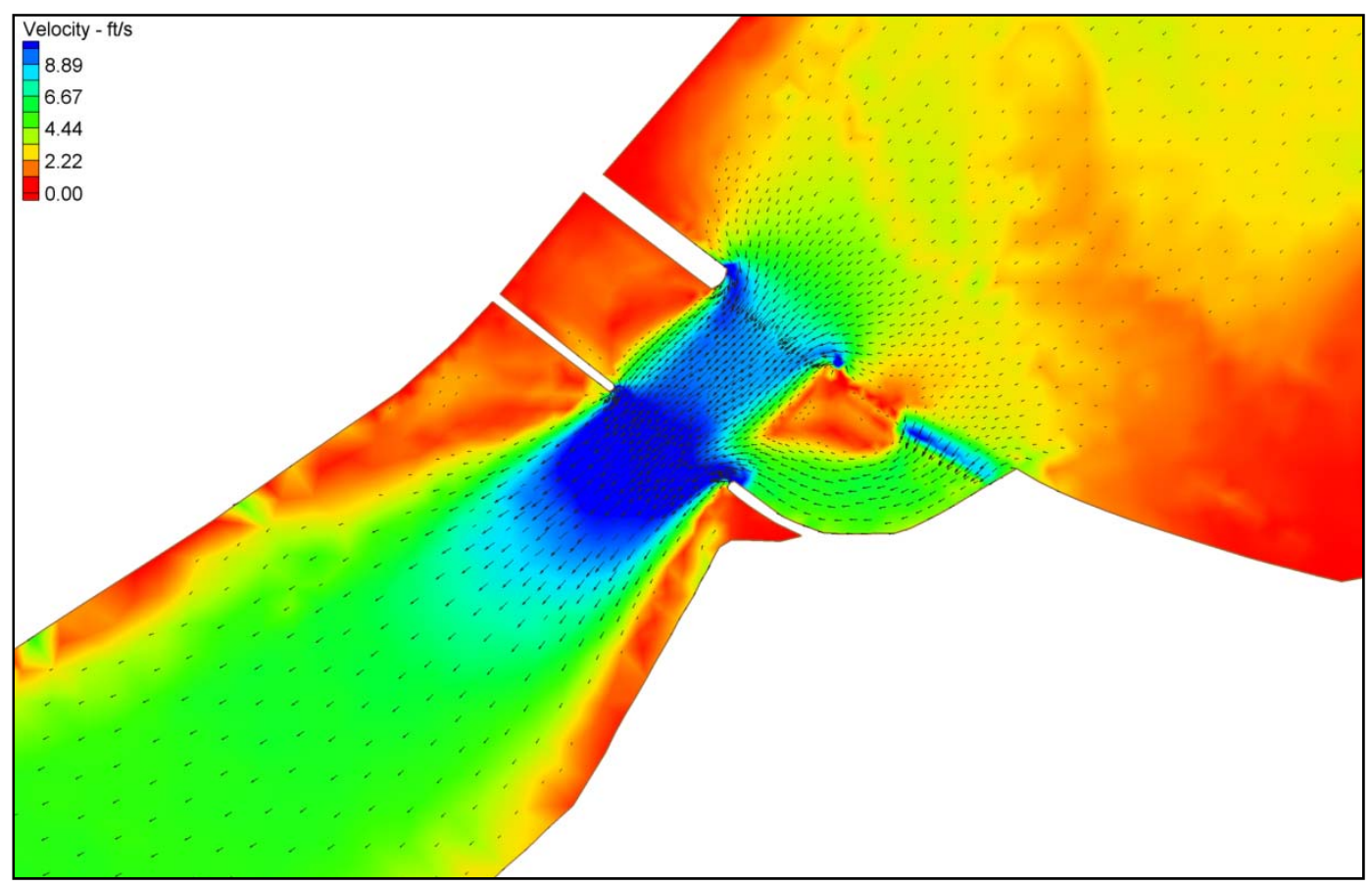

Figure 11. Maximum flow velocity and direction for the PMF event - Post-2010.

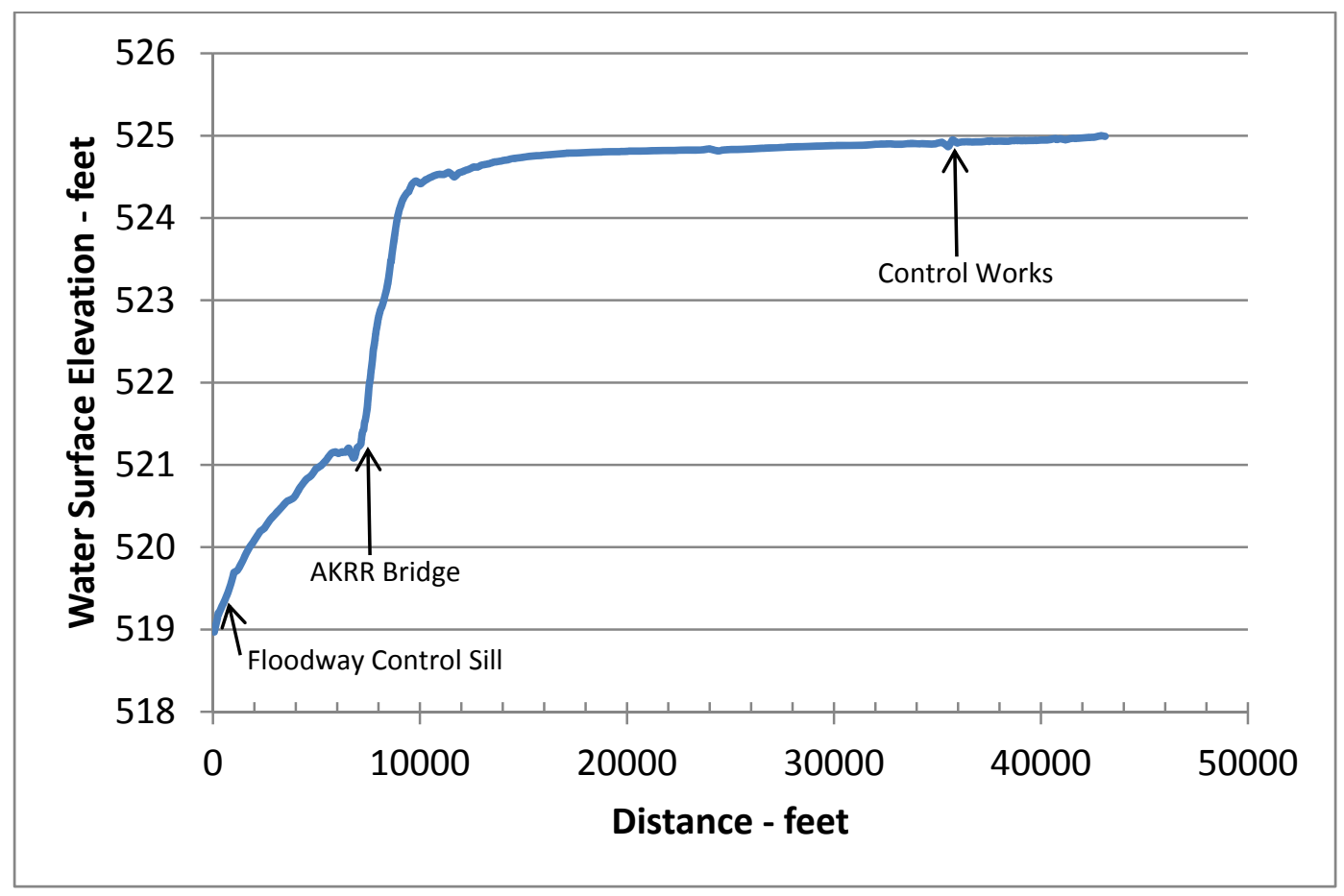

Figure 12. Longitudinal water surface profile at the peak of the PMF event - post-2010. 


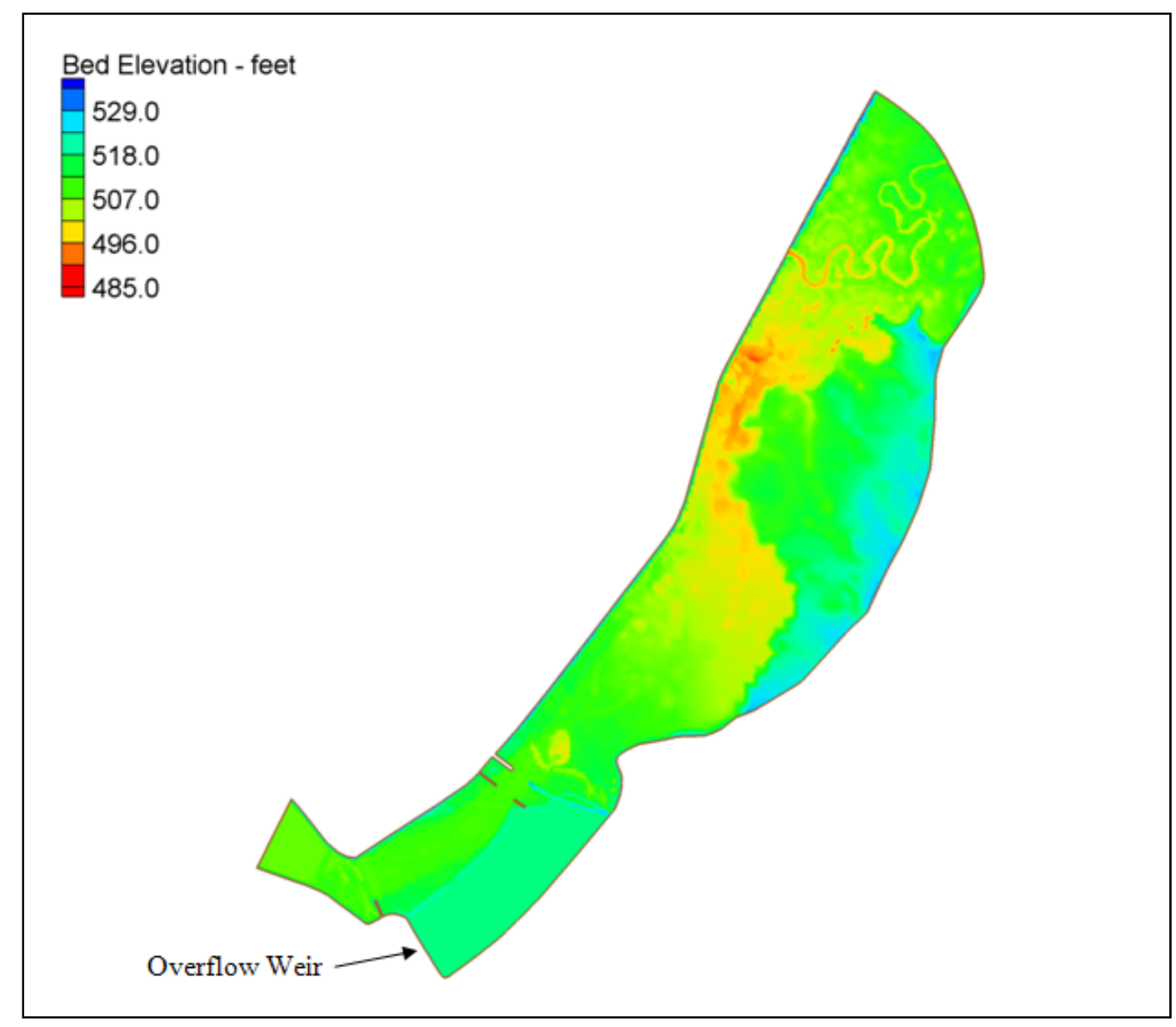

Figure 13. Base floodway mesh with overflow weir - Post-2010 + diversion overflow weir.

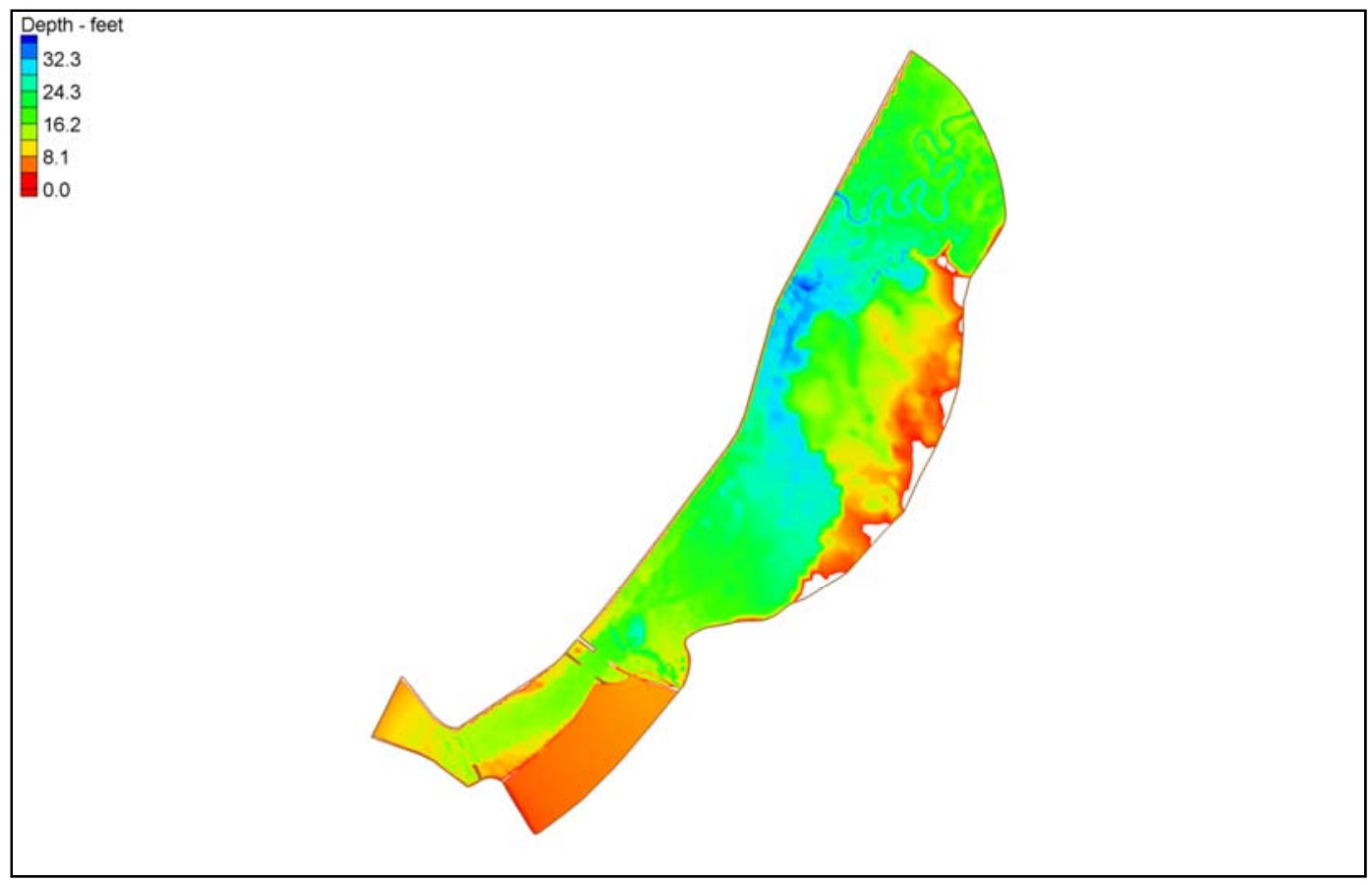

Figure 14. Maximum depth for the PMF event - Post-2010 + diversion overflow weir. 


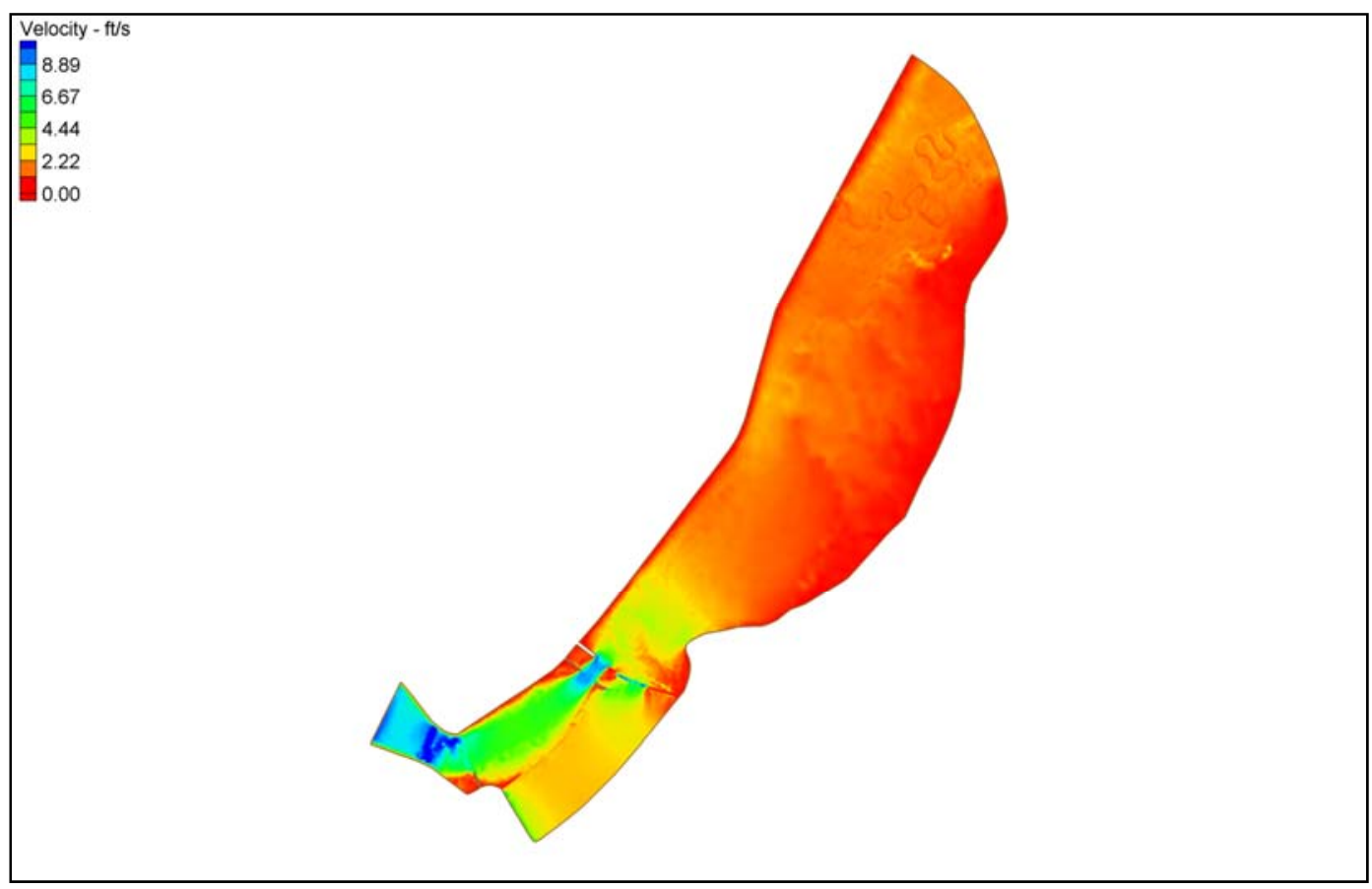

Figure 15. Maximum velocity for the PMF event - Post-2010 + diversion overflow weir.

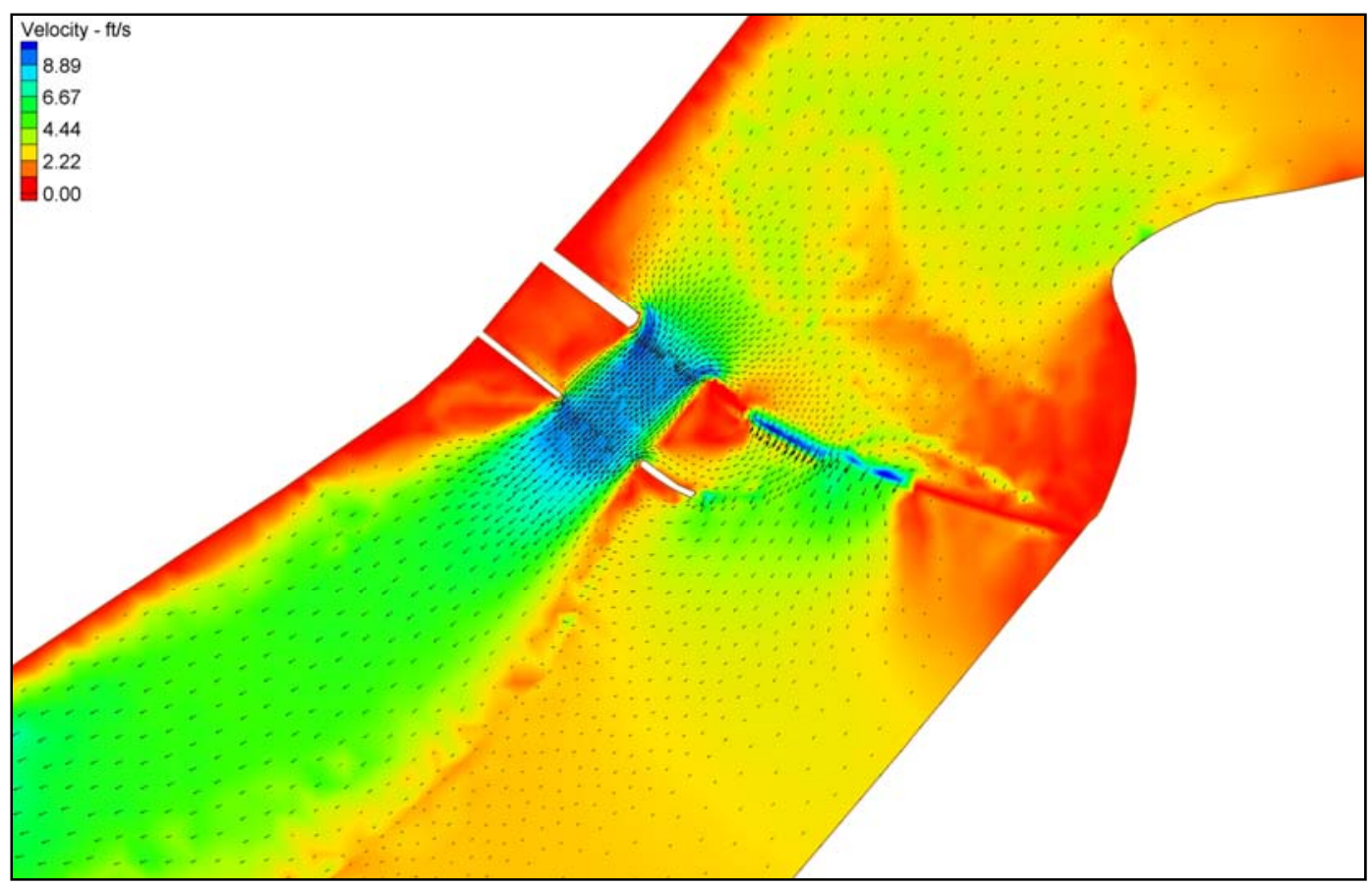

Figure 16. Maximum flow velocity and direction for the PMF event - Post-2010 + diversion overflow weir. 


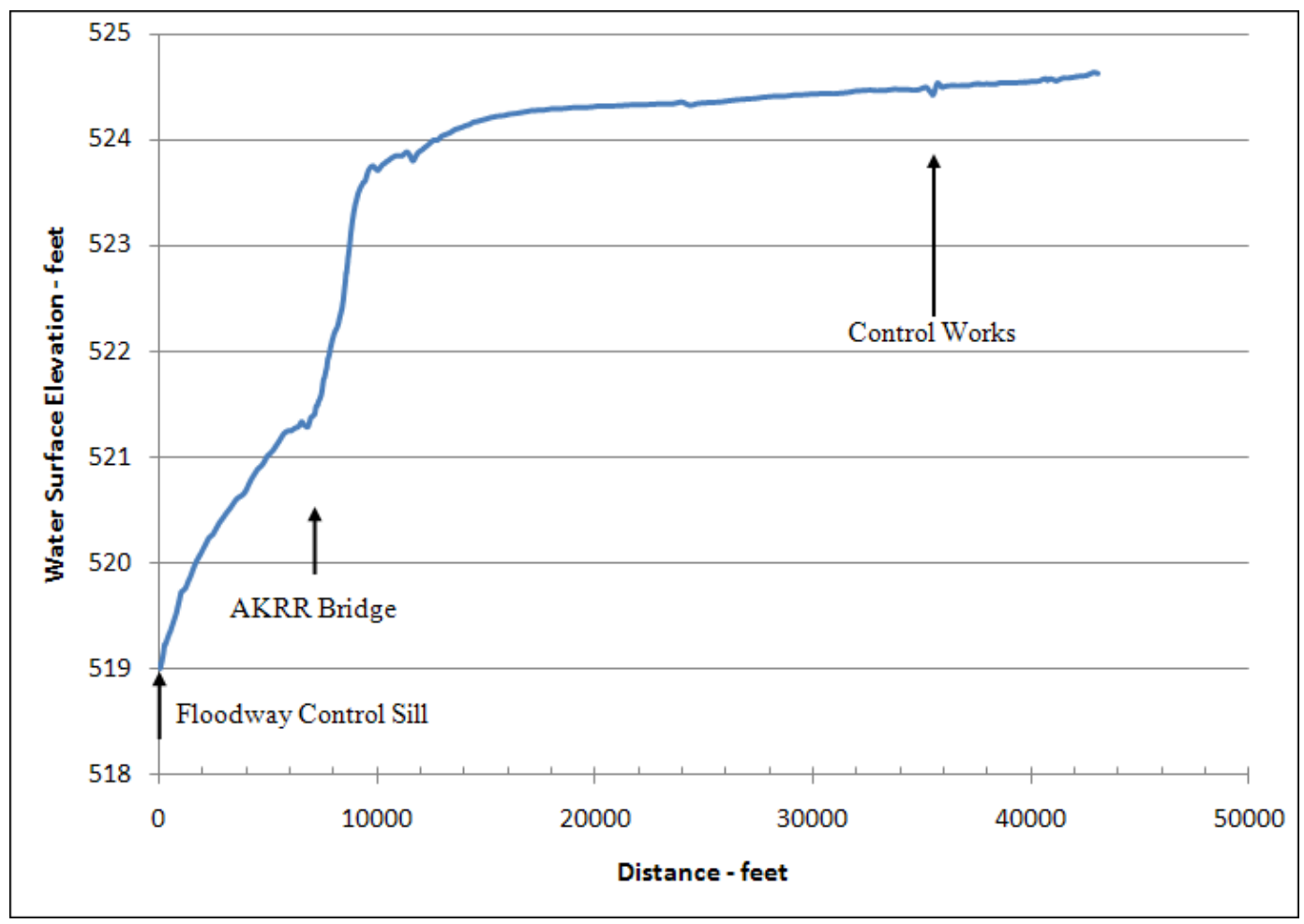

Figure 17. Longitudinal water surface profile at the peak of the PMF event - Post-2010+ diversion overflow weir. 


\section{Impact of Bridge Piers and Upstream Model Boundary Storage on Floodway Hydrodynamics}

Model simulations were conducted to investigate the influence of bridge piers and the upstream model boundary on backwater elevations. The portion of this effort was done using the HPC Jade running on 24 processors with 2-4 hour row times, and no adaptation. The head loss through the floodway section is a function of bed roughness (primarily vegetation), constriction of the channel due to bridge openings, and resistance of the bridge pilings. To determine the significance of the bridge piling resistance on water surface elevations, a model mesh was constructed that contained the bridge piling cross-sections (Figure 18) for both the highway and railroad bridges. For comparison purposes, a model mesh was also configured without the bridge piers but of similar resolution. The mesh with the piers has 51,798 nodes and 102,173 elements, and the mesh without the piers has 51,936 nodes and 102,815 elements. The PMF flood was simulated

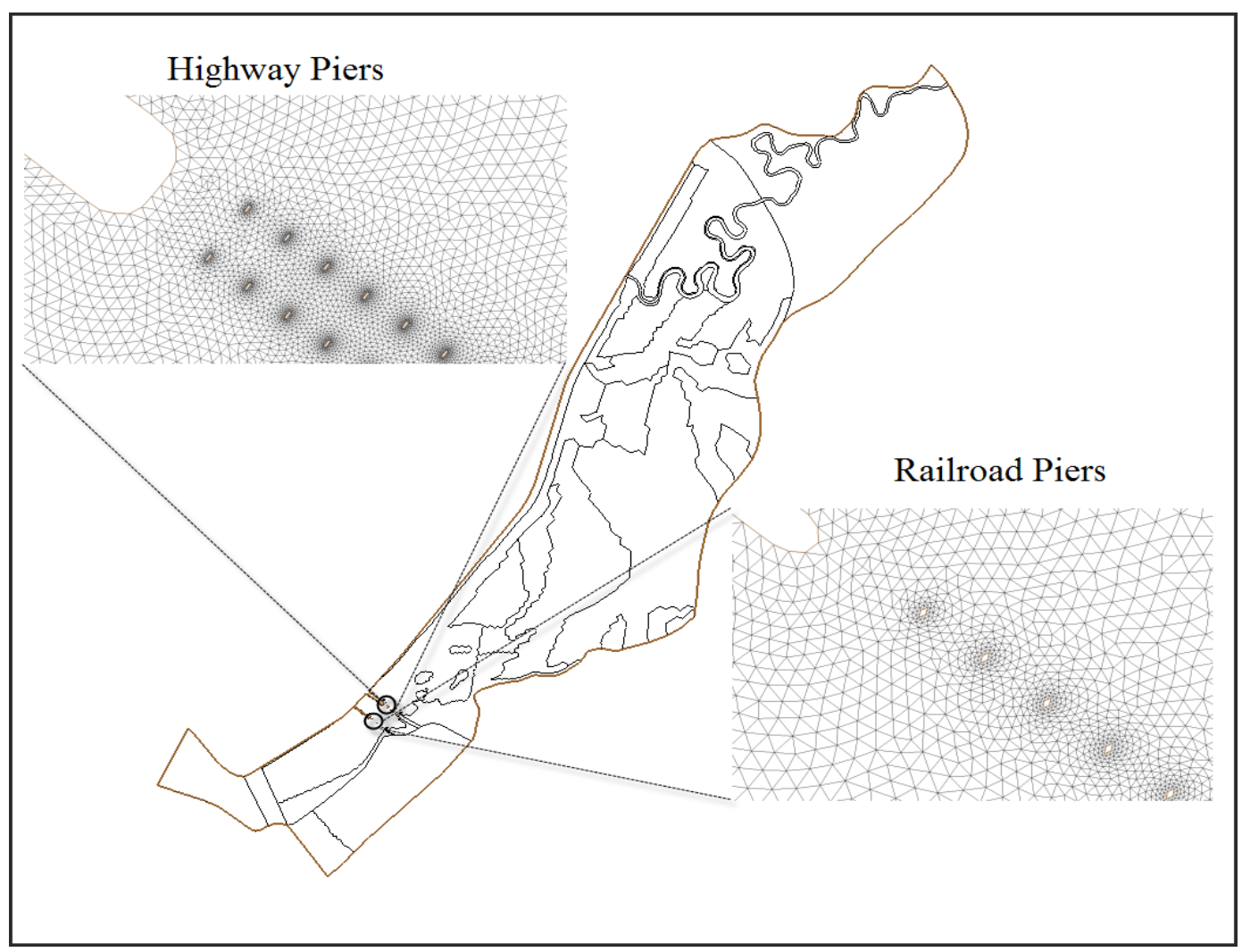

Figure 18. Location and orientation of bridge piers in the numerical mesh. 
with boundary conditions identical to the previous base model simulations. The reduction of flow area due to the bridge openings along with the bridge pier resistance could potentially increase the upstream water surface elevation and subsequent head on the dam.

Model simulations were also performed to evaluate the potential increase or decrease in water surface elevations due to the location of the upstream boundary. Two meshes (Figure 19) were generated (both meshes were the Post-2010 + diversion overflow weir used in the final PC model) for comparison purposes, one with an extended upstream section and one without (the base mesh upstream boundary). The PMF flood was simulated and water surface elevation profiles compared. Due to the increased resolution, both meshes required the use of the High Performance Computing (HPC).

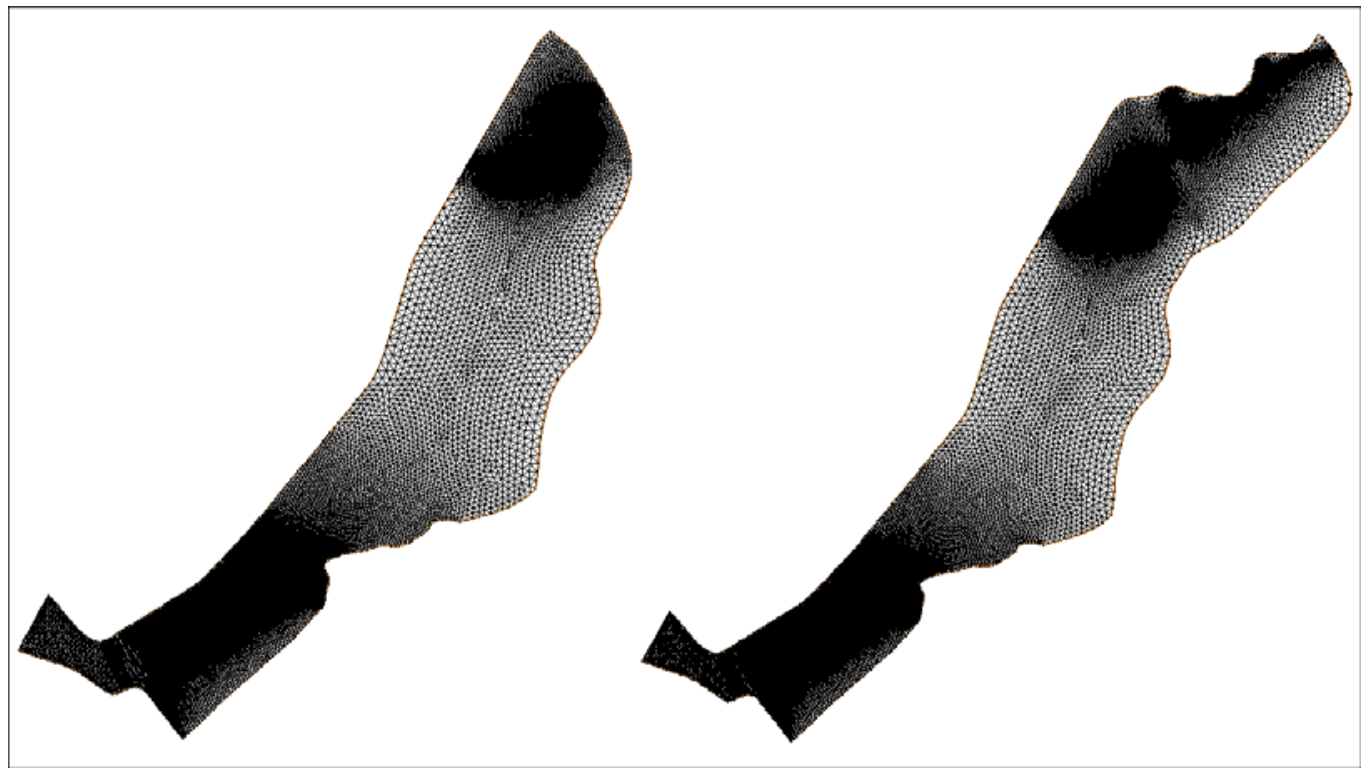

Figure 19. Base mesh extents (left side) compared to extended mesh extents (right side).

\subsection{HPC bridge pier/model boundary simulation results - PMF flood event}

The bridge pier comparison study indicated that the presence of the bridge piers increased the water surface elevation along the dam by approximately $0.1 \mathrm{ft}$ (Figure 20). Additional simulations were conducted to evaluate the impact of pier skin friction (originally no skin friction was applied on the piers) on water surface elevation profiles. Results of these simulations indicate that a negligible impact ( $\sim 0.001 \mathrm{ft})$ occurred when a Manning's $n$ value for rough concrete of 0.015 was applied to the pier. The low impact probably was due to the disproportionate ratio of surface area of the piers to the cross-sectional area of the flow. 


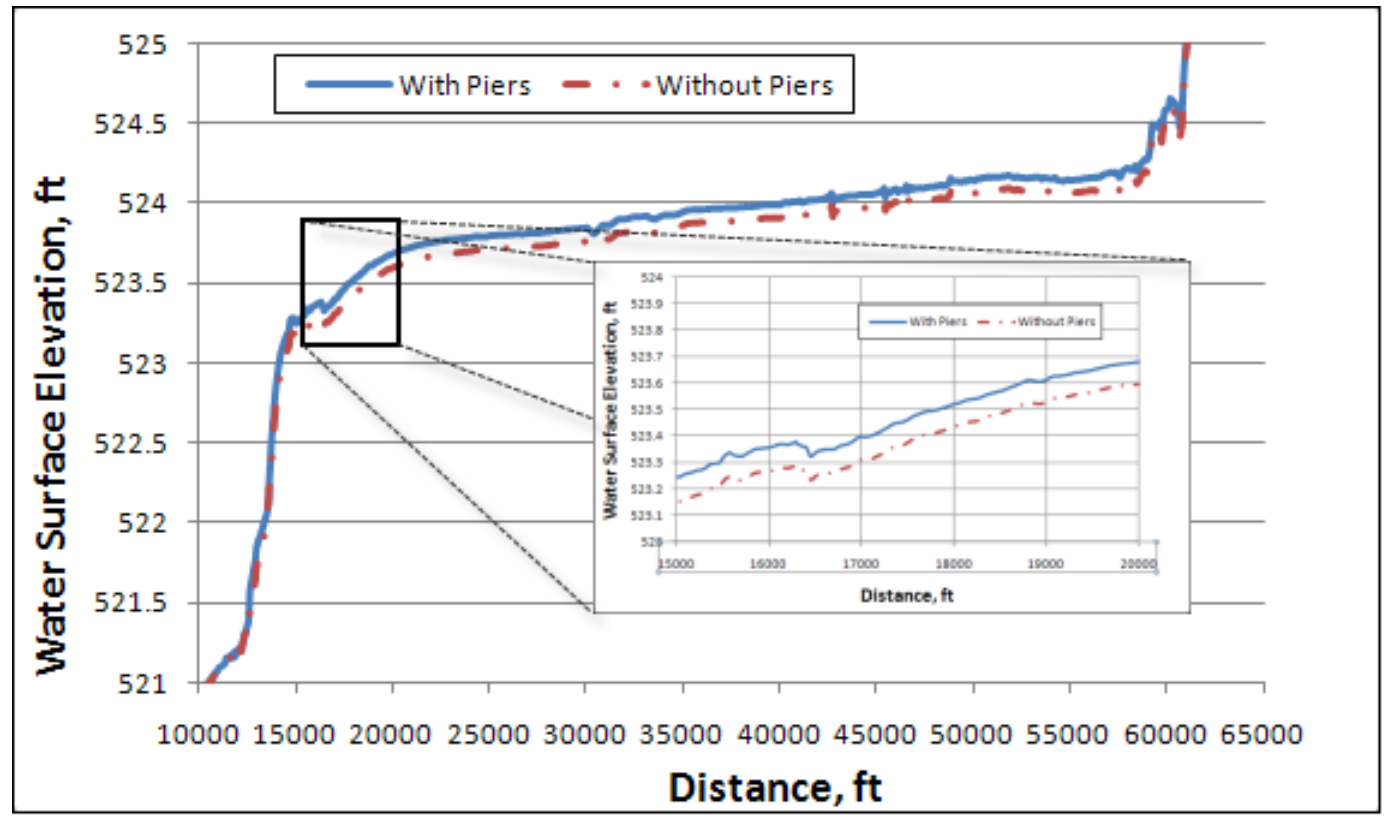

Figure 20. Comparison of water surface profile elevation with and without piers.

The model boundary simulation results indicate that the extended mesh reduced the backwater profile by approximately $0.1 \mathrm{ft}$ (Figure 21). In summary, model results indicate that the potential change in water surface elevation due to both the bridge piers and extended model mesh is negligible.

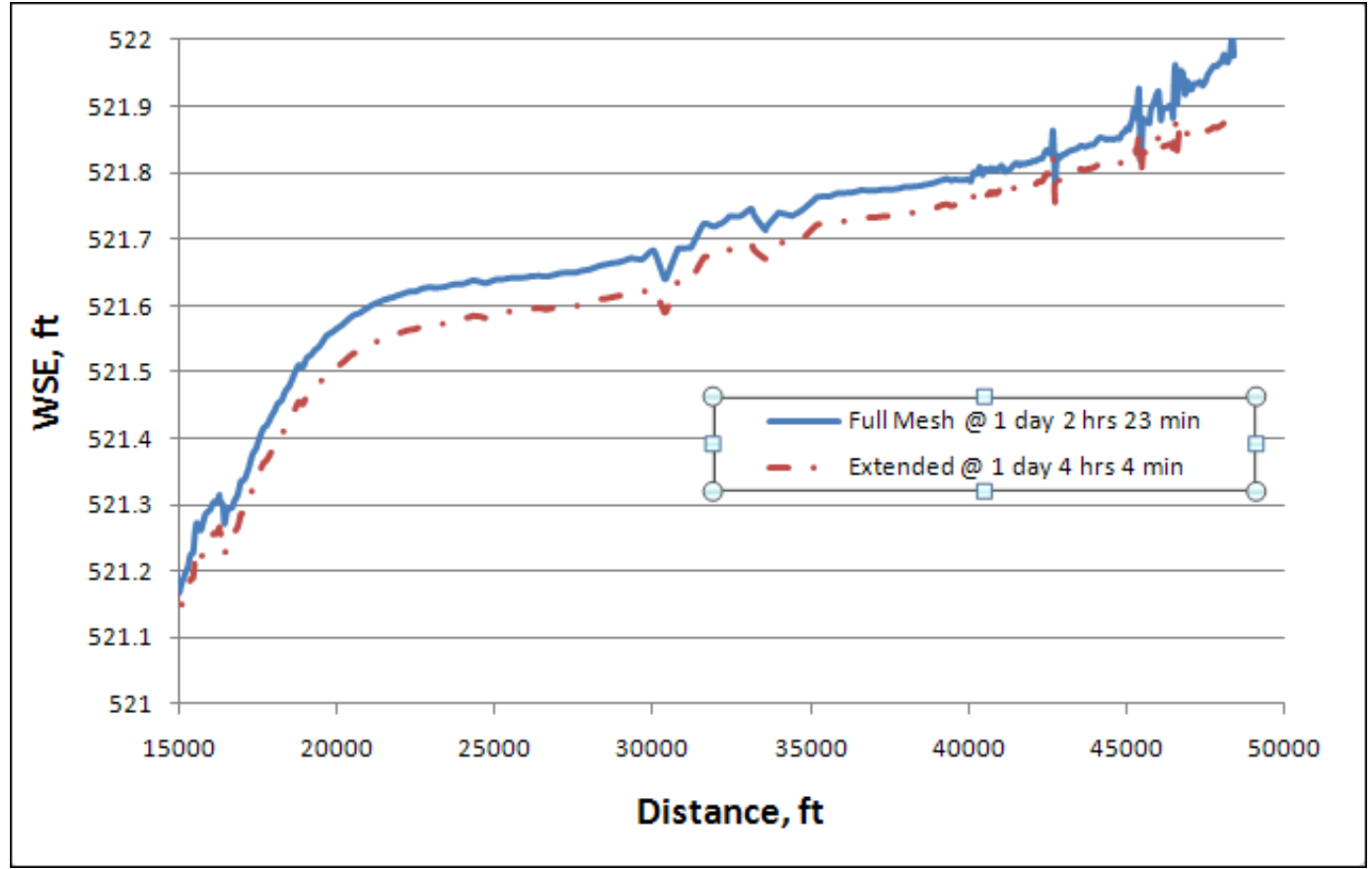

Figure 21. Comparison of water surface profiles for the full mesh (base condition) and extended mesh. 


\section{Alaska District Model Modifications}

Upon completion of the both mesh studies (PC and HPC), the model was delivered to the Alaska District for review and modification. A number of enhancements were made to the model by CEPOA District engineers to provide a more realistic hydrodynamic representation of the floodway. Because the primary resistance element in the floodway is vegetation, a comprehensive map of vegetation types was developed for the model domain. The floodway has maintained (mowed) areas, as well as thick brush and tall trees, thus both types of vegetation should be included in the model. In addition to providing a more realistic vegetation roughness detail, the District provided a more representative downstream stage boundary condition by including a short reach of the Tanana River, as well as improved bathymetry in the vicinity of the highway and railroad bridge openings. However, since there was limited impact, the bridge piers were not included in this set-up. A description of the vegetation roughness methodology in AdH is described below.

\subsection{Description of submerged vegetation roughness option in AdH}

Initially, the floodway bed roughness was simulated with a constant Manning's $n$ of 0.03 for comparing the base simulations (Pre-2010, Post2010, and Post-2010 + diversion overflow weir). Although this is a relatively low roughness value for low flow conditions where the vegetation is not submerged, it is more applicable to higher flows where roughness effects can be reduced significantly with depth.

To simulate the impacts of submerged vegetation on system hydrodynamics, an algorithm in AdH was used to calculate the Manning's $n$ based on vegetation height and effective roughness height of the submerged aquatic vegetation. Figure 22 presents the change in roughness ratio as a function of the ratio of the water depth to the height of vegetation. Appendix $B$ presents the empirical equations used for the submerged aquatic vegetation roughness calculations. If the water surface is below the vegetation, the computation computes a relatively high roughness. As the depth of water over the vegetation increases, the impact of the vegetation on roughness decreases. 


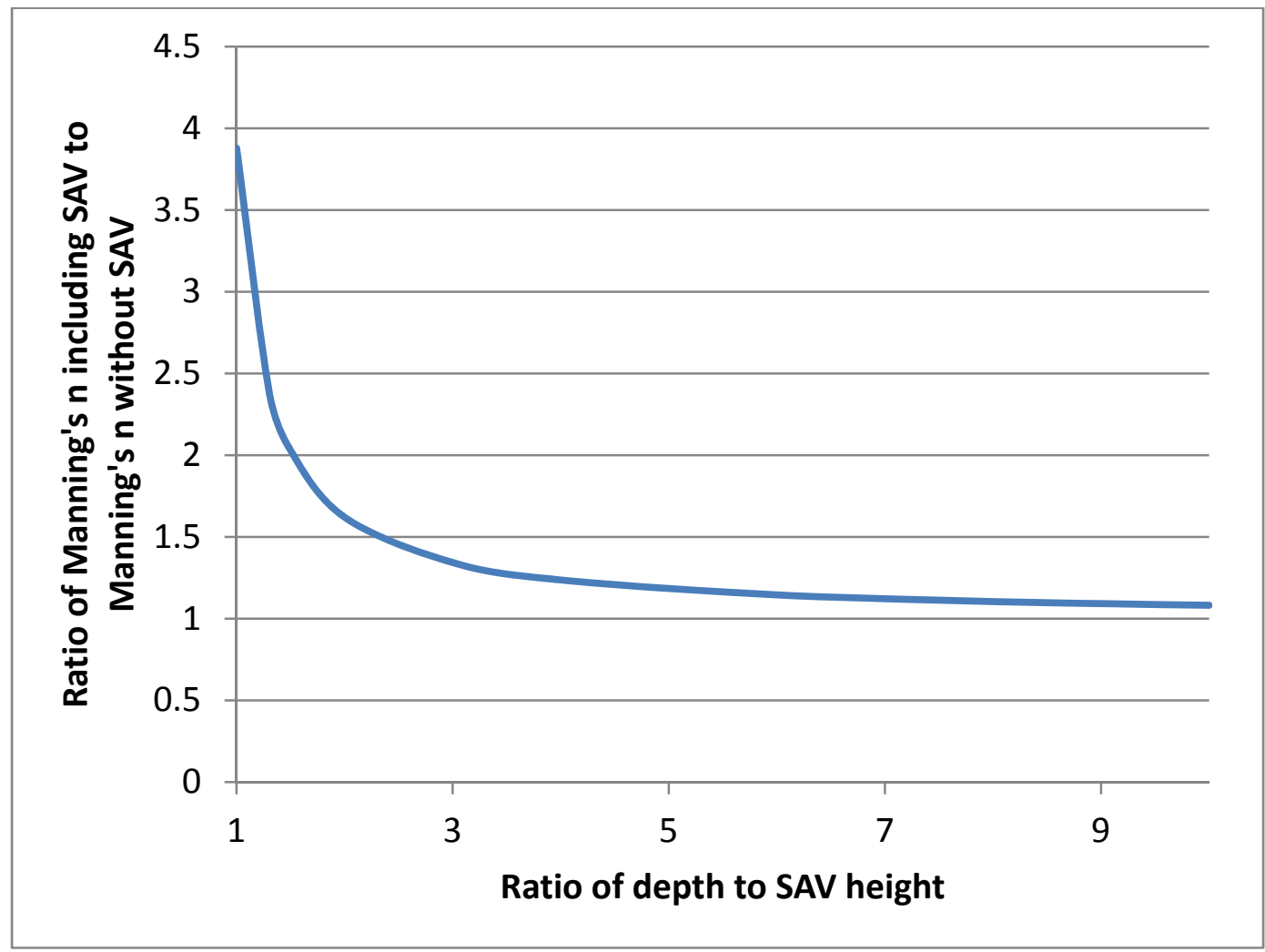

Figure 22. Impact of water depth over submerged vegetation on roughness.

\subsection{Description of un-submerged vegetative roughness in AdH}

The un-submerged vegetation option assumes that the vegetation is tall enough to always be out of the water. Unlike the submerged vegetation option, as the flow depth increases, the resistance increases due to the increasing cross-sectional area of the vegetation. The input to AdH consists of the bed roughness height, the average stem diameter of the vegetation, and the average stem density of the vegetation. The relationship between the roughness height of the bed and the Manning's $n$ is presented as:

$$
K_{s}=\left(8.25 * \sqrt{g} * \frac{n}{K_{n}}\right)^{6}
$$

with $K_{s}$ the bed roughness height, $g$ gravity, $n$ the Manning's roughness coefficient, and $K_{n}$ the coefficient for metric (1.0) or English (1.486) units. Figure 23 presents the change in roughness (Manning's $n$ ) as a function of relative stem density. 


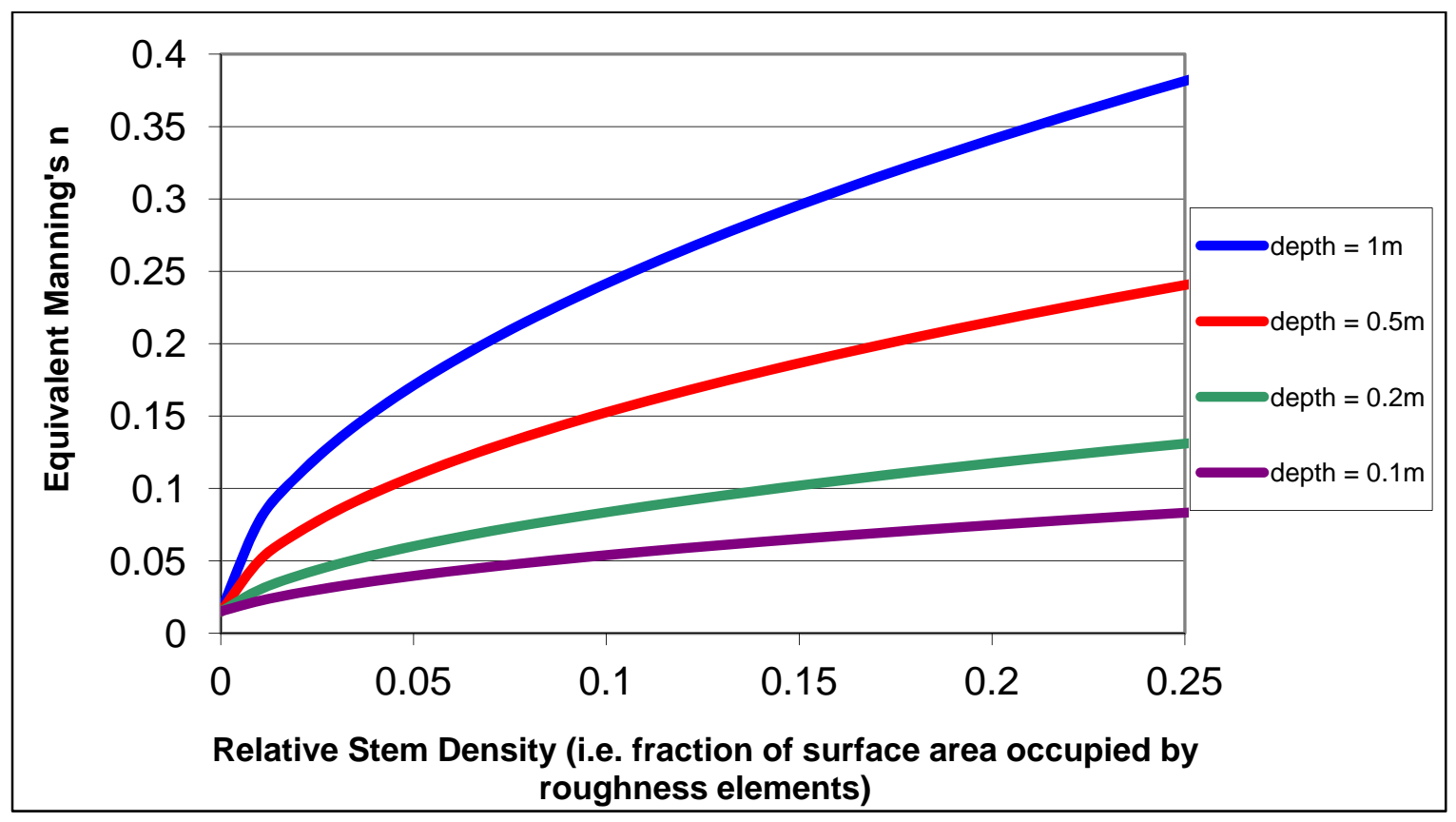

Figure 23. Roughness as a function of relative stem density.

\subsection{Final mesh HPC model simulation - PMF flood event}

The final mesh, that includes District modifications, is presented in Figure 24. Note that the downstream stage boundary for the model is dictated by the back water surface elevation of the Tanana River, which has separate discharge and stage boundary conditions. The Tanana River portion of the model was based on coarse topographic mapping with estimated bathymetry in the active channel areas. This portion of the model domain was included to provide for a realistic tailwater condition for the overflow section of the floodway and the rapidly spreading flow areas as water exits the lower floodway sill. The tailwater elevation, roughness and discharge on the Tanana River were varied to determine if water surface elevations within the floodway are sensitive to the Tanana river tail water conditions.

For these sensitivity simulations, the water surface elevation at the control works varied less than $0.3 \mathrm{ft}$. The final Tanana River parameters chosen for subsequent simulations were: tailwater elevation of 510 feet NAVD88, Manning's $n$ roughness value of 0.03 and discharge of 250,000 cfs. This approximately corresponds to a standard project flood on the Tanana River and was the same tailwater discharge utilized in the original physical model studies. Modeled water surface elevations within the Tanana River just upstream of the sill groin are within one foot of the of the HEC-2 model used during the design and recertification of the Tanana River Levee. 


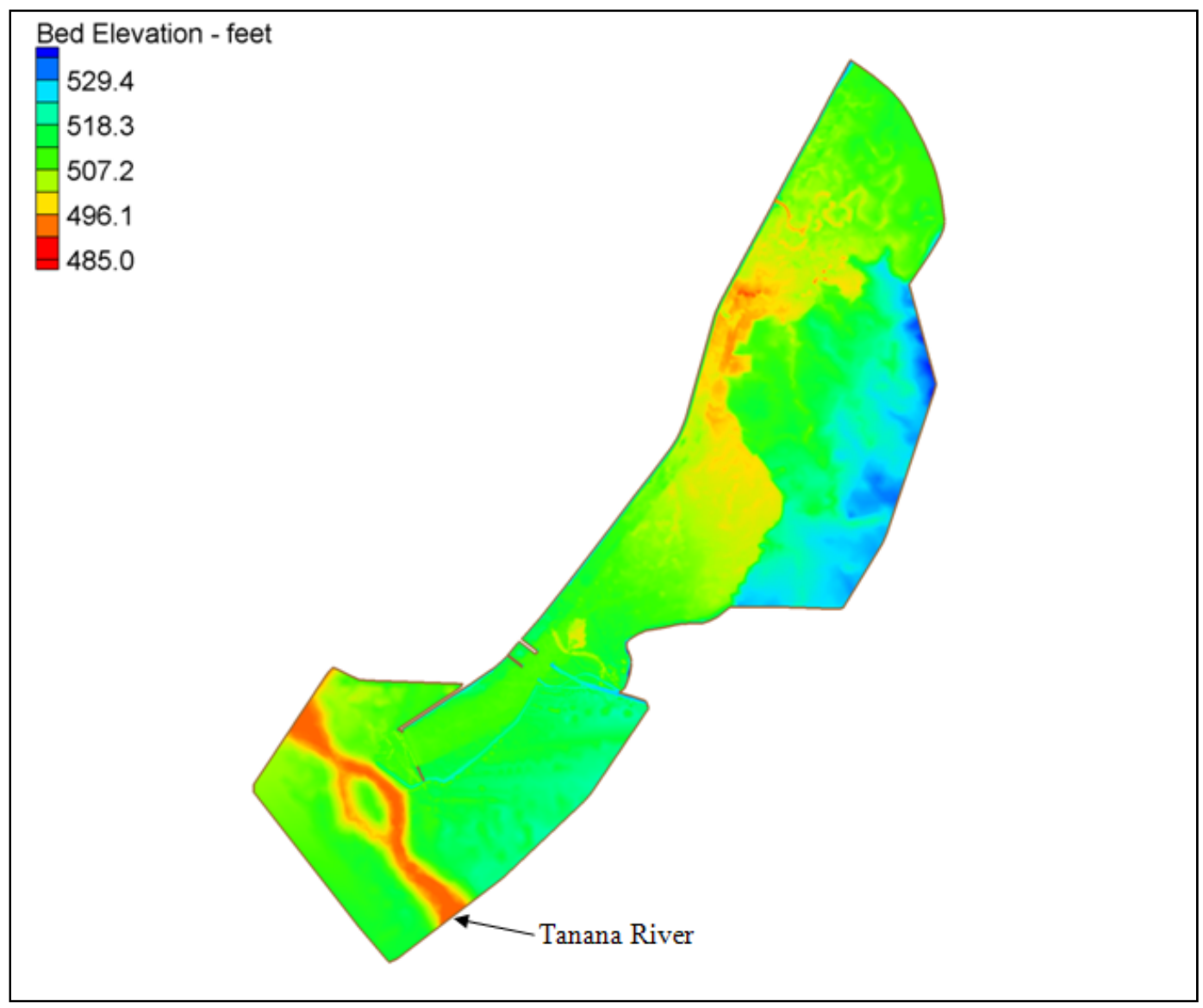

Figure 24. Final floodway mesh with Tanana River segment.

The vegetation area descriptions assigned by the District to the model are provided in Figure 25 and Table 2. The vegetation map was developed by delineating areas of similar vegetation roughness based on interpretation of aerial photos. Roughness areas were grouped into nine classes varying from road surfaces to densely forested areas. Of these nine classes, the two most important roughness classes to consider are the maintained areas of the floodway and the densely forested areas. These two vegetation classes comprise a majority of the areas within the floodway that convey water.

The maintained area of the floodway was modeled using a submerged roughness formulation available within AdH from Christensen (1985) with average vegetation characteristics taken from Jacobs and Wang (2003). This method relates roughness not only to properties of the vegetation, but also water depth. A bed roughness height of 0.5 feet with a submerged vegetation height of 3.0 feet was selected for the maintained portions of the floodway. Converting this bed roughness height results in a Manning's $n$ value of 0.028 which is then increased due to the submerged vegetation 


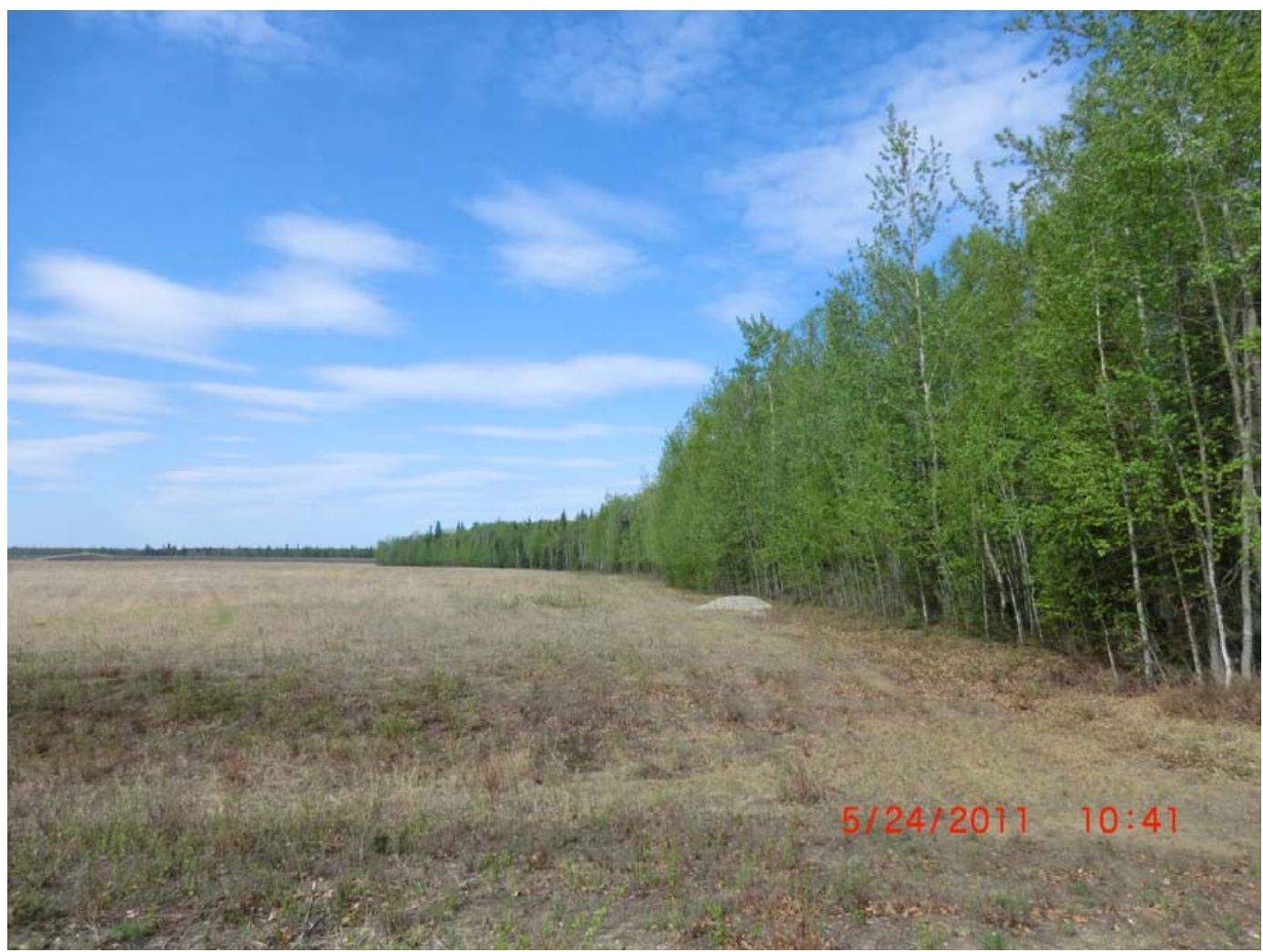

Figure 25. Photograph of a typical section of maintained floodway on the left and an area of dense trees on the right.

Table 2. Final roughness designations in the final AdH model (see Figure $\mathbf{2 6}$ for location of material in mesh)

\begin{tabular}{|l|l|l|l|l|l|l|l|}
\hline $\begin{array}{l}\text { Material } \\
\text { Number }\end{array}$ & Description & Manning $\mathrm{n}$ & $\begin{array}{l}\text { SAV } \\
\text { Roughness }\end{array}$ & $\begin{array}{l}\text { SAV Height } \\
\mathrm{ft}\end{array}$ & $\begin{array}{l}\text { URV } \\
\text { Roughness }\end{array}$ & $\begin{array}{l}\text { URV Diameter } \\
\mathrm{ft}\end{array}$ & $\begin{array}{l}\text { URV } \\
\text { Density }\end{array}$ \\
\hline 1 & Road Bed & 0.02 & N/A & N/A & N/A & N/A & N/A \\
\hline 2 & Reseeded Grass & N/A & 0.5 & 3.0 & N/A & N/A & N/A \\
\hline 3 & Viscosity Area & N/A & 0.5 & 0.5 & N/A & N/A & N/A \\
\hline 4 & Tanana River & 0.03 & N/A & N/A & N/A & N/A & N/A \\
\hline 5 & Light Brush & N/A & 4.0 & 5.0 & N/A & N/A & N/A \\
\hline 6 & Light Forest & N/A & N/A & N/A & 4.0 & 0.5 & 0.002 \\
\hline 7 & Heavy Brush & N/A & N/A & N/A & 4.0 & 0.75 & 0.004 \\
\hline 8 & Dense Forest & N/A & N/A & N/A & 4.0 & 0.75 & 0.004 \\
\hline 9 & Chena Channel & 0.035 & N/A & N/A & N/A & N/A & N/A \\
\hline 10 & Sill Clearing & N/A & 1.0 & 2.0 & N/A & N/A & N/A \\
\hline
\end{tabular}

Notes:

SAV - Submerged Aquatic Vegetation

URV - Un-submerged Rigid Vegetation

Roughness, Height, and Diameter units in feet 


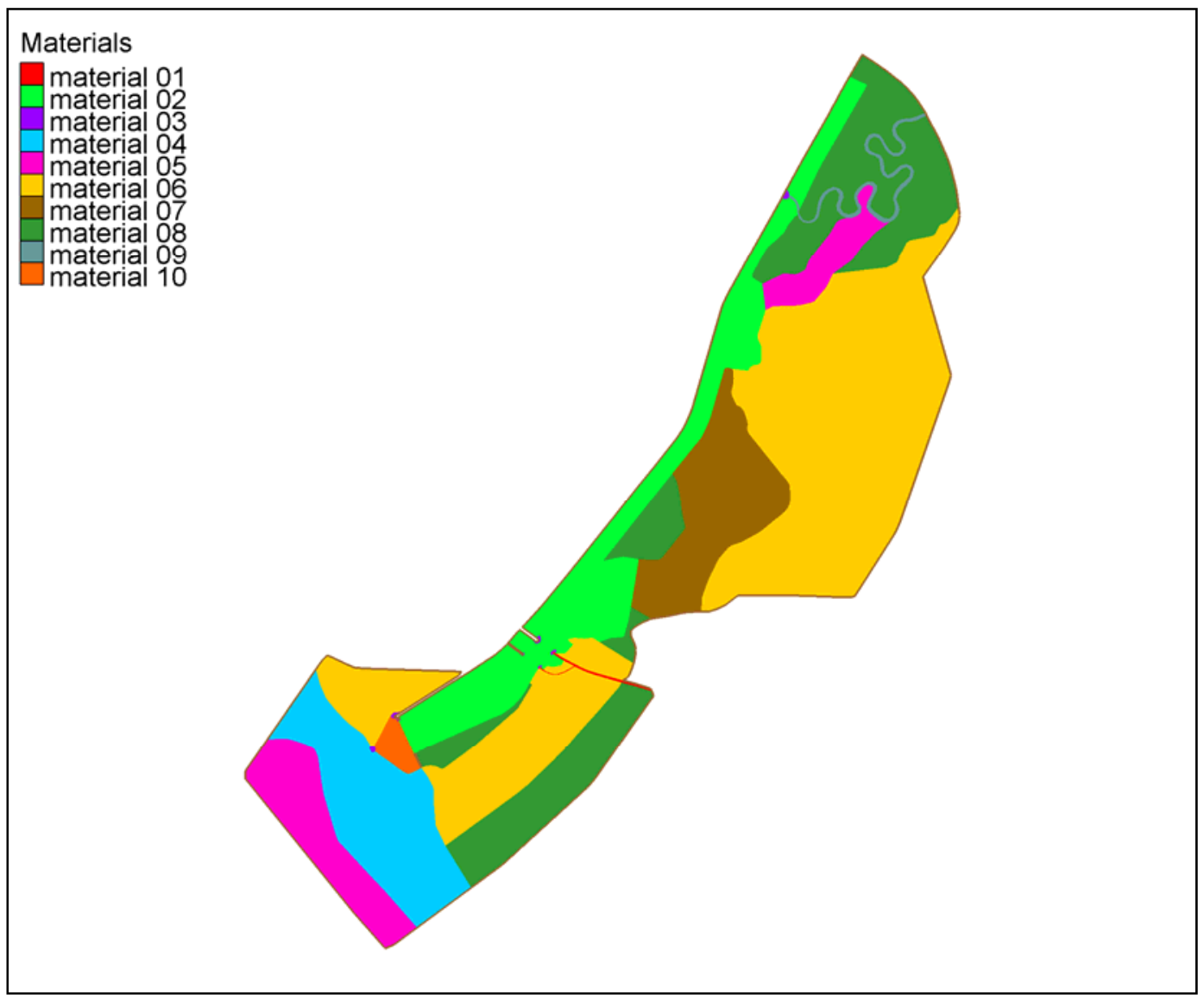

Figure 26. Final floodway bed roughness map used in the Alaska District PMF simulation (see Table 2 for material descriptions).

based on the flow depth and vegetation height as shown in Figure 22. The sensitivity of both the bed roughness height and submerged vegetation height within the maintained portions of the floodway was examined. Varying the bed roughness height from 0.5 feet to 4.0 feet increased the water surface elevation at the control works by 0.3 feet. The submerged vegetation height was varied from 0.5 feet to 6.0 feet. This resulted in a 1.0 foot difference at the control works. The final value of 0.5 feet for bed roughness height and a vegetation height of 3.0 feet was selected for the model. The selection was based on the Districts experience with the system. A Manning's $n$ value of 0.028 was chosen as a reasonable roughness value for the maintained floodway considering the smooth grading and straight and uniform nature of the floodway. An average vegetation height of 3 feet was considered reasonable considering that the floodway is maintained on a three year rotating schedule. Previous studies used $n$ values between 0.025 and 0.030 for the maintained portions of the floodway. Figure 25 shows a picture of the maintained portion of the floodway adjacent to a heavily treed area. 
Several published values are available for density of forested areas in floodplains around Fairbanks (Hollingsworth et al. 2006; McGuire et al. 2010 and Viereck et al. 1993). Tree density values range from $0.000014 \mathrm{ft}^{2} / \mathrm{ft}^{2}$ to $0.006 \mathrm{ft}^{2} / \mathrm{ft}^{2}$ for forested areas within the floodplain. A conservative value of $0.00425 \mathrm{ft} / \mathrm{ft}$ was selected as the base model condition with an average trunk diameter of 9 inches. Tree density was varied by increasing the density by 100 percent and decreasing the density by 50 percent Varying the un-submerged tree density changed the water surface elevation at the control works by approximately +/- $0.1 \mathrm{ft}$. Figure 26 shows the final mapped vegetation used in the model.

Figures 27-30 present the peak flow water depth and velocity, with Figure 31 presenting the peak flow longitudinal water surface profile. As with the base model simulations, the peak flow velocity between the highway and railroad bridges was on the order of 8-9 ft/sec. Approximately 75 percent of the peak PMF flow exited the floodway over the sill, whereas 25 percent of the flow overtopped the road and flowed into the Tanana upstream of the sill. The peak water surface elevation at the Chena River control station was approximately 525.4 feet NAVD 88.

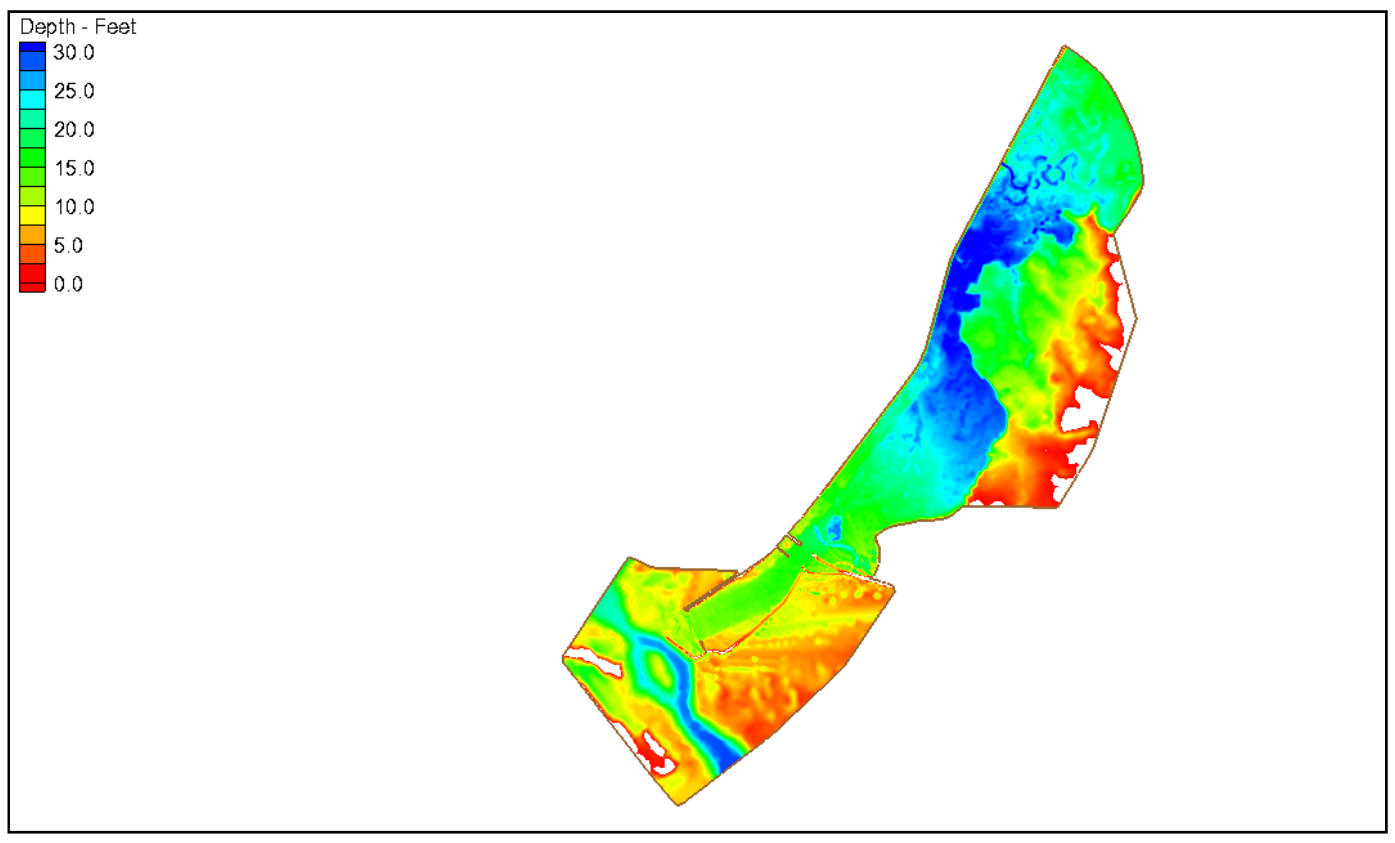

Figure 27. Maximum depth for the PMF event - Post-2010 + diversion overflow weir + Tanana River. 


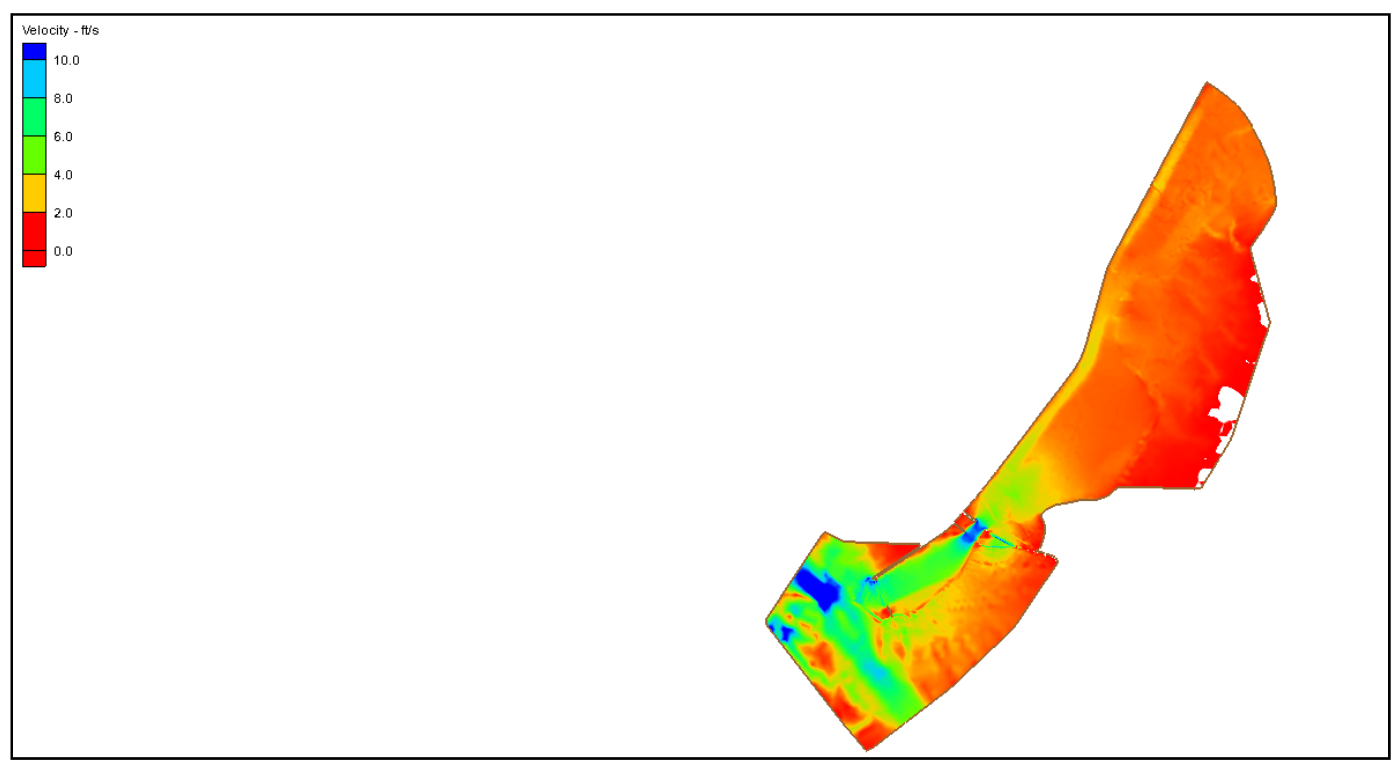

Figure 28. Maximum velocity for the PMF event - Post-2010 + diversion overflow weir + Tanana River.

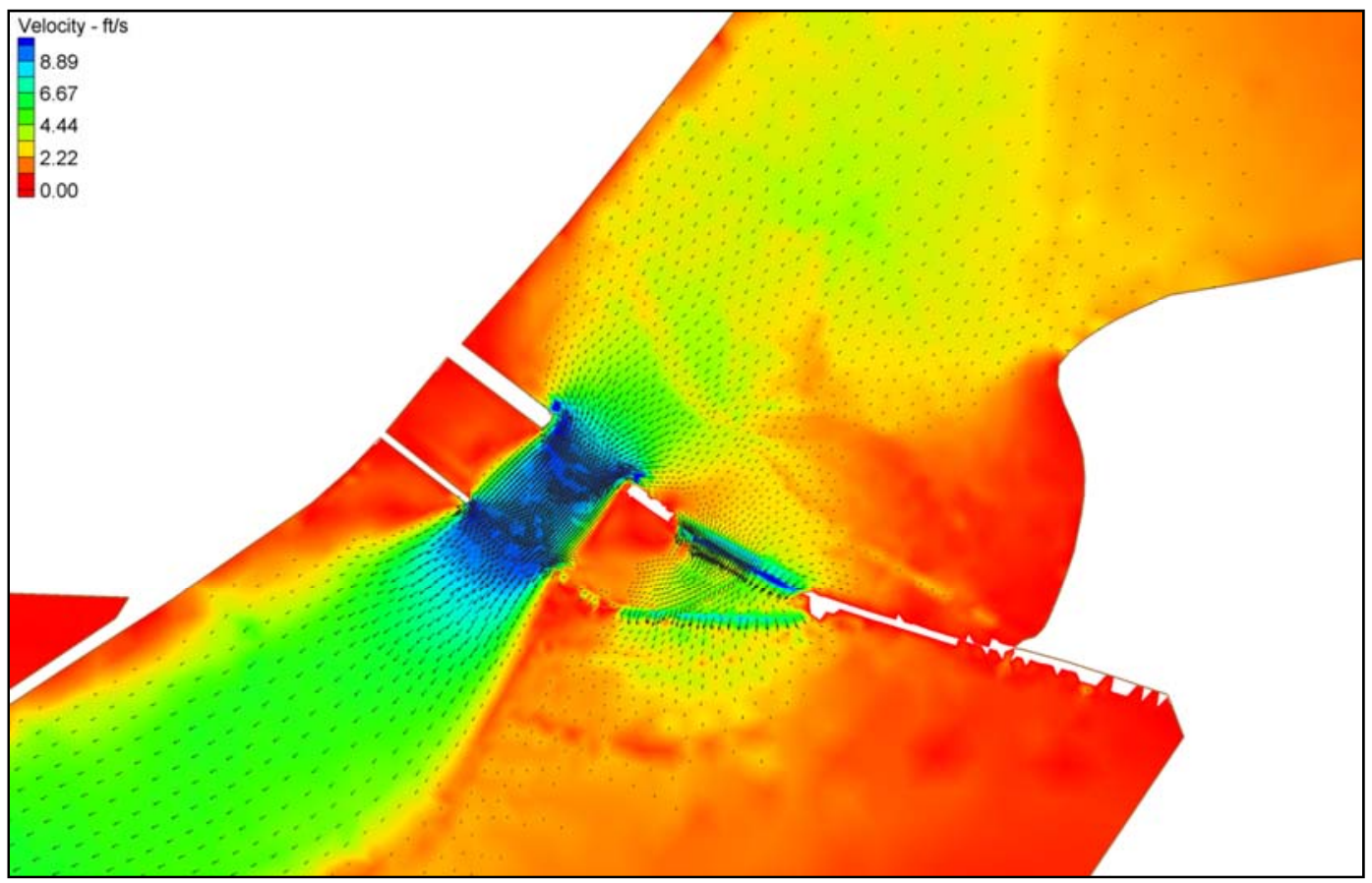

Figure 29. Maximum flow velocity and direction for the PMF event - Post-2010 + diversion overflow weir + Tanana River. 


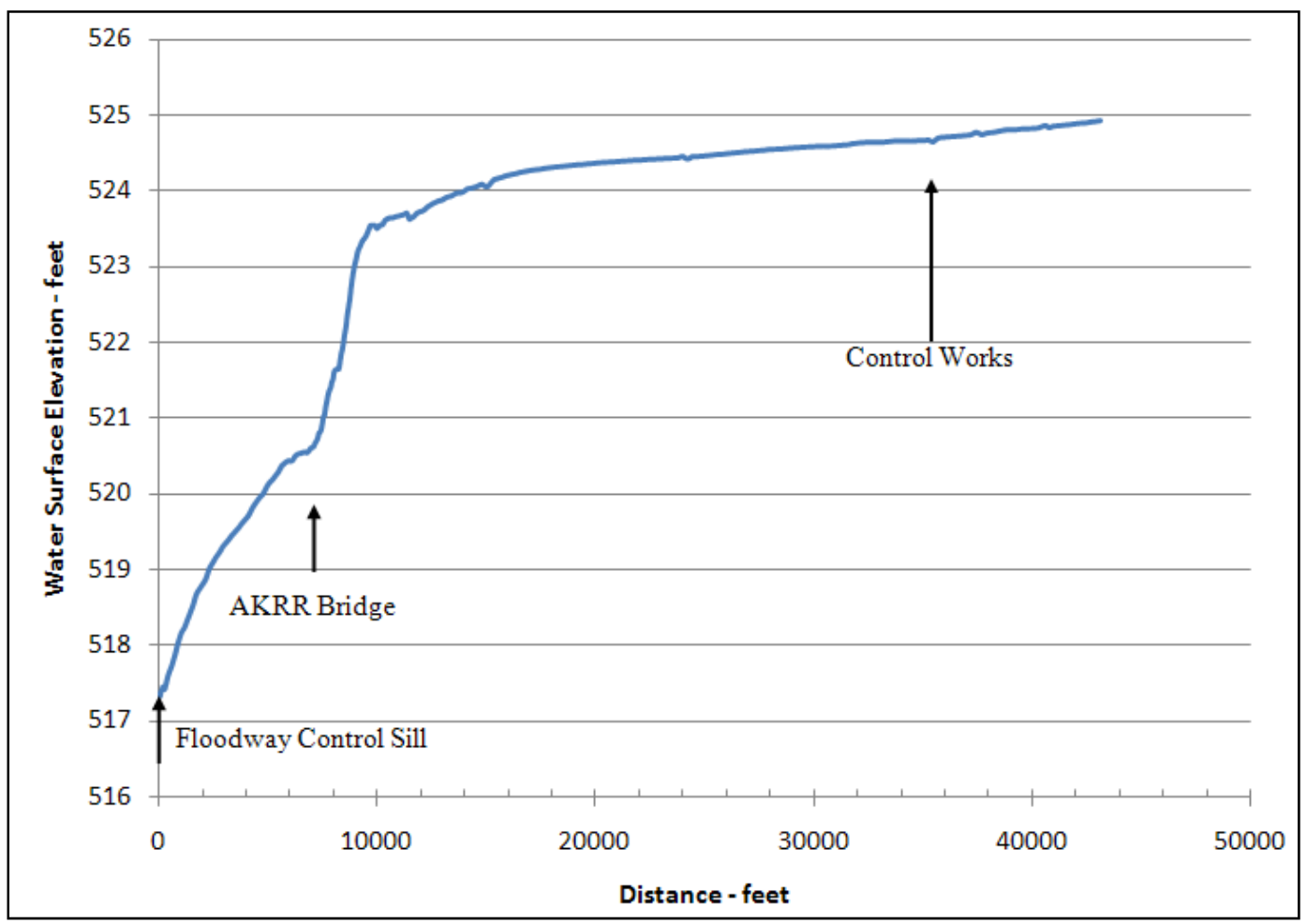

Figure 30. Water surface elevation profile at the peak of the PMF event - Post-2010 + diversion overflow weir + Tanana River.

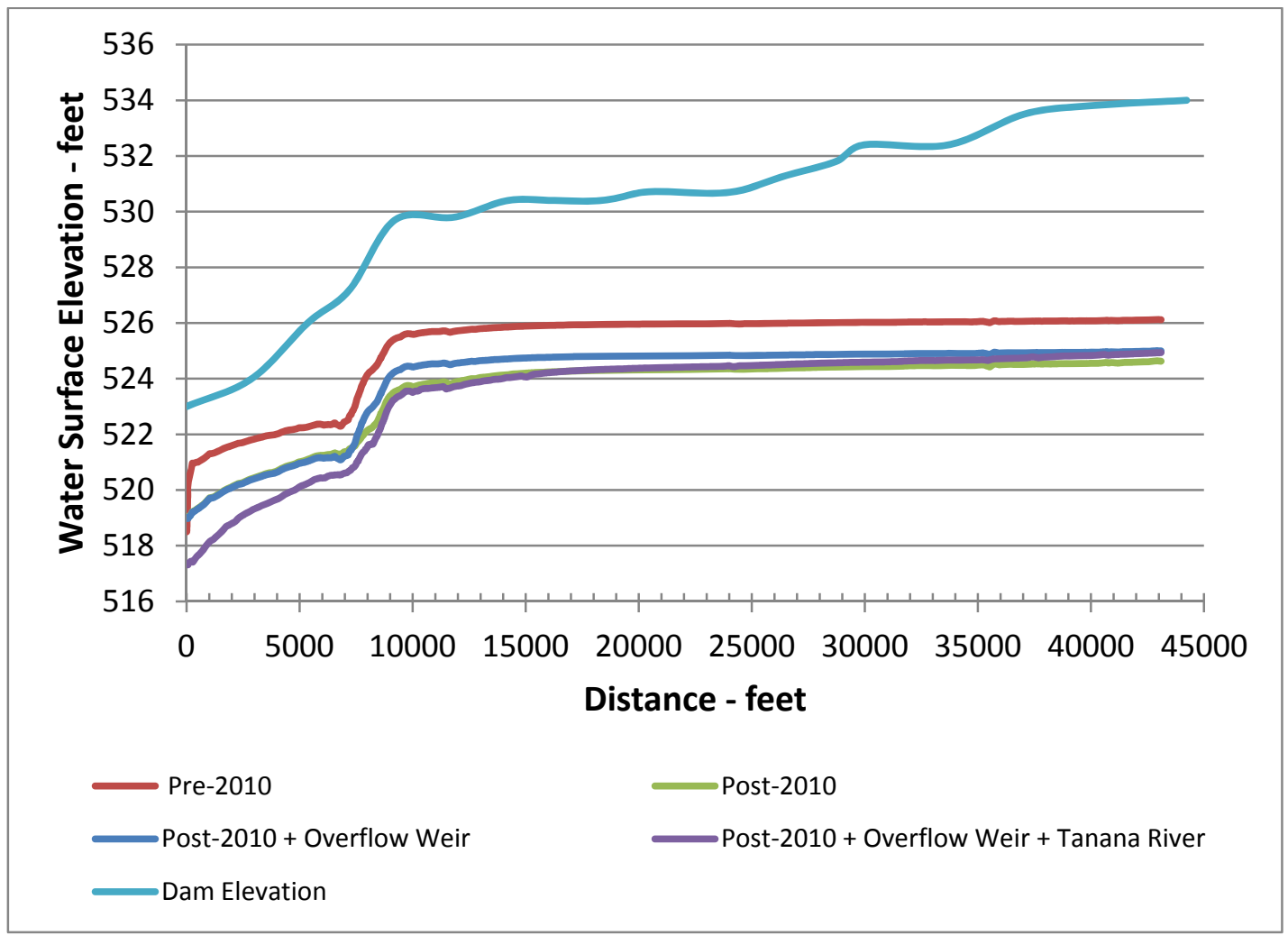

Figure 31. Comparison of simulated water surface profiles with the Moose Creek Dam crest elevation profile 


\section{Discussion}

The longitudinal water surface elevation profiles for peak PMF flow for all simulations are presented in Figure 31, along with the Moose Creek dam crest elevation. All of the simulations indicate that the $4.0 \mathrm{ft}$ freeboard requirement for the dam is met for the post-2010, post-2010 + diversion overflow weir, and post-2010+diversion oveflow weir + Tanana River models using the current PMF hydrograph. A comparison between the base floodway only model and the base weir model indicate that accounting for the highway overtopping and re-routing of flow to the east may potentially reduce the head of water on the dam at the peak PMF flow (160,000 cfs) by as much as a 0.5 feet. The longitudinal maximum water surface profiles differ somewhat for the developed models due to how the downstream stage boundary is defined and the assignment of a more representative vegetation roughness scheme in the final hydraulic model. 


\section{Conclusions}

- An efficient AdH PC model was developed that could be simulated using a PC for the Moose Creek Floodway. Simulation times for the base floodway models ranged from $2-4$ hours for the five day PMF hydrograph simulation.

- The peak flow floodway PC model results the Pre-2010 scenario compare favorably to the physical model results in terms of flow velocity between the bridges and water surface elevation from the sill to just above the highway bridge.

- The head loss due to the combination of the resistance of the bridge pilings and the extended upstream model boundary is approximately 0.1 feet for the PMF peak flow.

- The addition of the Tanana River segment along with a detailed vegetation roughness map to the floodway model provided a more realistic representation of the systems hydrodynamics and overflow pathways than previous model studies.

- Lowering the sheet pile sill elevation to the post-2010 elevation (507.10 feet) decreased water surface elevations by approximately one foot for the PMF event at the Chena River control works.

- A 2-D Adaptive Hydraulics model has been developed that can be utilized to evaluate dam modification alternatives that impact the geometry and hydrodynamics of the lower floodway. 


\section{References}

Alaska District. Moose Creek Dam Floodway Value Engineering Proposal, Appendix A, August 1987

Alaska District. Evaluation of Lowering the Moose Creek Dam Floodway Control Sill, Fairbanks, Alaska. Chena River Lakes project letter report No. 27, February 9, 2010

Berger, R.C. 1997. "HIVEL 2D v2.o Users Manual”. Waterways Experiment Station, US Army Corps of Engineers, Vicksburg, MS 39180.

Berger, R.C., J.N. Tate, G.L. Brown, and G. Savant. 2010. Adaptive Hydraulics User Manual, A Two-Dimensional Modeling System Developed by the Coastal and Hydraulics Laboratory, US Army Engineering Research and Development Center.

Hollingsworth, T.N., M.D. Walker, F.S. Chapin III, and A.L. Parsons. 2006. Scaledependent environmental controls over species composition in Alaskan black spruce communities. Can. J. For.Res. 36(7): 1781-1796. doi:10.1139/Xo6-061.

Jacobs, J.M. and M. Wang. 2003. Atmospheric momentum roughness to determine stage-discharge relationships in vegetated flood plains. Journal of Hydrologic Engineering, 8(2), 99-104.

Martin, S.K., G. Savant, and D.C. McVan. 2011. Two Dimensional Numerical Model of the Gulf Intracoastal Waterway near New Orleans: Case Study. Journal of Waterway, Port, Coastal, and Ocean Engineering, ASCE. Doi:10.1061/(ASCE)WW.19435460.0000119 .

McGuire, A.D., R.W. Ruess, A. Lloyd, J. Yarie, J.S. Clein, and G.P. Juday. 2010. Vulnerability of white spruce tree growth in interior Alaska in response to climate variability: dendrochronological, demographic, and experimental perspectives. Can. J.

For. Res. 40(7). This issue. doi:10.1139/Xo9-206.

Reeve, D.E., A. Soliman, P.Z. Lin. 2008. Numerical study of combined overflow and wave overtopping over a smooth impermeable seawall. Coastal Engineering. 55, 155166.

Rodi, W. 1993. Turbulence models and their application in hydraulics - a state of the art review, Balkema: Leiden.

Savant, G., C. Berger, T. McAlpin, and J. Tate. 2010. Intelligent Adaptive Time-Step Control for Modeling Rapidly-Evolving Hydrodynamic Flows in Adaptive Hydraulics (ADH). System Wide Water Resources Program, TN-SWWRP-10-6.

Stockstill, R.L. and J.M. Vaughan. 2009. Numerical Model Study of the Tuscarawas River below Dover Dam, Ohio. Coastal and Hydraulics Engineering Technical Report, ERDC/CHL TR-09-17. Vicksburg, MS: U.S. Army Engineering Research and Development Center. 
Stockstill, R.L., J.M. Vaughan, and S.K. Martin. 2010. Numerical Model of the Hoosic River Flood-Control Channel, Adams, MA. Coastal and Hydraulics Engineering Technical Report, ERDC/CHL TR-10-01. Vicksburg, MS: U.S. Army Engineering Research and Development Center.

Tate, J.N., T.C. Lackey, and T.O. McAlpin. 2010. Seabrook Fish Larval Transport Study. Coastal and Hydraulics Engineering Technical Report, ERDC/CHL TR-10-12. Vicksburg, MS: U.S. Army Engineering Research and Development Center.

Viereck, L.A., C.T. Dyrness, and M.J. Foote. 1993. An overview of the vegetation and soils of the floodplain ecosystems of the Tanana River, interior Alaska. Can.J. For. Res. 23:889-898. 


\section{Appendix A: Adaptive Hydraulics Equations}

The equations solved in AdH are the 2-D non-linear shallow water equations. Although not applicable for turbulent flow or where vertical acceleration is present, these equations have proven successful in describing non-breaking conditions (Reeve et al. 2008). Fundamentally, the equations are derived on the assumption that the vertical velocity component is negligible. For this study, the primary application is to simulate a flood surge, and it is assumed that the equations are applicable for the given conditions.

Neglecting shear stress and fluid pressure at the free surface, the 2-D shallow water equations as implemented within $\mathrm{AdH}$ are written as:

$$
\frac{\partial Q}{\partial t}+\frac{\partial F_{x}}{\partial x}+\frac{\partial F_{y}}{\partial y}+H=0
$$

where

$$
\begin{gathered}
Q=\left\{\begin{array}{l}
h \\
u h \\
v h
\end{array}\right\} \\
F_{x}=\left\{\begin{array}{c}
u h \\
u^{2} h+\frac{1}{2} g h^{2}-h \frac{\sigma_{x x}}{\rho} \\
u v h-h \frac{\sigma_{y x}}{\rho}
\end{array}\right\} \\
F_{y}=\left\{\begin{array}{c}
v h \\
u v h-h \frac{\sigma_{y x}}{\rho} \\
v^{2} h+\frac{1}{2} g h^{2}-h \frac{\sigma_{y y}}{\rho}
\end{array}\right\}
\end{gathered}
$$


and

$$
H=\left\{\begin{array}{c}
0 \\
g h \frac{\partial z_{b}}{\partial x}+n^{2} g \frac{u \sqrt{u^{2}+v^{2}}}{h^{1 / 3}} \\
g h \frac{\partial z_{b}}{\partial y}+n^{2} g \frac{v \sqrt{u^{2}+v^{2}}}{h^{1 / 3}}
\end{array}\right\}
$$

The Reynolds stresses ( $\sigma$ ), where the first subscript indicates the direction and the second indicates the face on which the stress acts, are due to turbulence. The Reynolds stresses are determined using the Boussinesq approach to the gradient in the mean currents:

$$
\begin{aligned}
& \sigma_{x x}=2 \rho v_{t} \frac{\partial u}{\partial x} \\
& \sigma_{y y}=2 \rho v_{t} \frac{\partial v}{\partial y}
\end{aligned}
$$

and

$$
\sigma_{x y}=\sigma_{y x}=2 \rho v_{t}\left(\frac{\partial u}{\partial y}+\frac{\partial v}{\partial x}\right)
$$

Here $v_{t}=$ kinematic eddy viscosity, which varies spatially where turbulence closure is achieved through the algebraic eddy viscosity formulation described by Rodi (1993).

The equations are discretized using the finite element method in which $u$, $v$, and $h$ are represented as linear polynomials on each element.

The set of partial differential equations represented in Equation 1 solved with the finite element method using the approach of Petrov-Galerkin that incorporates a combination of a Galerkin test function and a non Galerkin component to control oscillations due to convection (Berger 1997).

AdH utilizes a Pseudo-Transient Continuation and Switched Evolution Relaxation inspired time-step size selection algorithm (Savant et al. 2010). 
This technique computes the optimal time-step size dependent on the L2 norm of the system of equations. This selection algorithm provides an efficient technique for a temporally accurate solution of rapidly varying hydrodynamic and sediment flows. Additional information about the $\mathrm{AdH}$ model can be accessed at www.adh.usace.army.mil. 


\section{Appendix B: Submerged Aquatic Vegetation Roughness Calculations}

The following empirical formulation computes the ratio of the Manning's $n$ roughness coefficient with and without submerged aquatic vegetation as a function of the ratio of the water depth to height of the submerged aquatic vegetation. The following variable definitions apply:

$$
\begin{aligned}
& d=\text { water depth } \\
& h=\text { effective roughness height } \\
& R=\text { ratio of water depth to effective roughness height } \\
& C d s a v=\text { drag coefficient for vegetation } \\
& C d \text { standard }=\text { drag coefficient for bed } \\
& \text { Cdratio }=\text { ratio of } \mathrm{Cd} \text { sav to } \mathrm{Cd} \text { standard } \\
& \text { nratio }=\text { Manning's } n \text { ratio } \\
& \begin{array}{c}
\mathrm{R}=\frac{\mathrm{d}}{\mathrm{h}} \\
\mathrm{t}=0.667^{*} \frac{\mathrm{d}}{\mathrm{R}} \\
\mathrm{k}=0.1^{*} \frac{\mathrm{d}}{\mathrm{R}} \\
\beta=29.7^{*} \frac{\mathrm{d}}{\mathrm{k}} \\
\mathrm{\gamma}=1-\left(29.7^{*} \frac{\mathrm{t}}{\mathrm{k}}\right) \\
\mathrm{C}_{\mathrm{d}} \mathrm{sav}=2^{*}\left(\frac{\mathrm{bpl}=\beta+\gamma}{(\mathrm{bpl} *(\ln (\mathrm{bpl})-1)+1)}\right)^{2}
\end{array}
\end{aligned}
$$




$$
\begin{aligned}
\mathrm{C}_{\mathrm{d}} \text { standard } & =2 *\left(\frac{0.4^{*} \beta}{((\beta+1) *(\ln (\beta+1)-1)+1)}\right)^{2} \\
\mathrm{C}_{\mathrm{d}} \text { ratio } & =\frac{\mathrm{C}_{\mathrm{d}} \text { sav }}{\mathrm{C}_{\mathrm{d}} \text { standard }} \\
\text { nratio } & =\mathrm{C}_{\mathrm{d}} \text { ratio }^{0.5}
\end{aligned}
$$




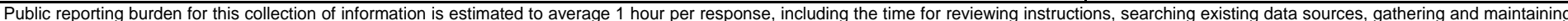

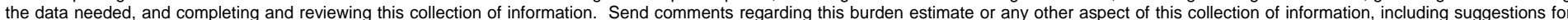

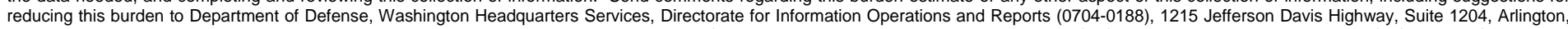

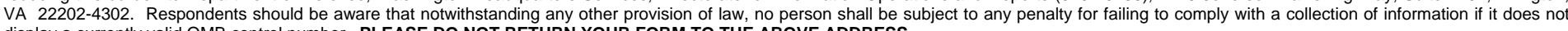
display a currently valid OMB control number. PLEASE DO NOT RETURN YOUR FORM TO THE ABOVE ADDRESS.

\begin{tabular}{l|c|}
$\begin{array}{l}\text { 1. REPORT DATE (DD-MM-YYYY) } \\
\text { September } 2012\end{array}$ & $\begin{array}{c}\text { 2. REPORT TYPE } \\
\text { Final Report }\end{array}$ \\
\hline
\end{tabular}

\section{TITLE AND SUBTITLE}

Two Dimensional Hydrodynamic Analysis of the Moose Creek Floodway

3. DATES COVERED (From - To)

5a. CONTRACT NUMBER

\section{AUTHOR(S)}

Stephen H. Scott, Jeremy A. Sharp, Gaurav Savant, Crane Johnson, and Dee Ginter

\begin{tabular}{l|l|}
\cline { 2 - 2 } & 5e. TASK NUMBER \\
\cline { 2 - 2 } & 5f. WORK UNIT NUMBER \\
\hline 7. PERFORMING ORGANIZATION NAME(S) AND ADDRESS(ES) & $\begin{array}{c}\text { 8. PERFORMING ORGANIZATION REPORT } \\
\text { NUMBER }\end{array}$
\end{tabular}

Coastal and Hydraulics Laboratory

U.S. Army Engineer Research and Development Center

5b. GRANT NUMBER

5c. PROGRAM ELEMENT NUMBER

3909 Halls Ferry Rd, Vicksburg, MS 39180;

U.S. Army Corp of Engineer Alaska District

$22043^{\text {rd }}$ Street, JBER, AK 99506-0898

9. SPONSORING I MONITORING AGENCY NAME(S) AND ADDRESS(ES)

U.S. Army Corps of Engineers Alaska District

Anchorage, AK

ERDC/CHL TR-12-20

\section{DISTRIBUTION I AVAILABILITY STATEMENT}

Approved for public release; distribution is unlimited.

\section{SUPPLEMENTARY NOTES}

\section{ABSTRACT}

A two-dimensional Adaptive Hydraulics $(\mathrm{AdH})$ hydrodynamic model was developed to simulate the Moose Creek Floodway. The Floodway is located approximately 17 miles East of Fairbanks, Alaska, and is part of the Chena River Lakes Flood Control project. The Chena River floodway is designed to reduce the flood risk at Fairbanks, AK by re-routing flood flows into the Tanana River. The floodway control sill is designed to prevent backwater from the Tanana River from entering the floodway. A dam to the west and high ground to the east contain the flow in the floodway connecting the Chena River to the Tanana River. Controlling factors for the head on the dam are; floodway channel surface roughness, channel constrictions due to the highway and railroad bridge crossings, and the elevation of the downstream control sill. The effort completed three tasks. The first developed a two-dimensional floodway model to be efficiently executed on a personal computer. The second task investigated the impact of highway and railroad bridge piers on floodway water surface profiles during flood conditions. Finally, the model was optimized to predict impacts of changes to floodway vegetation and Tanana River stage on backwater profiles and was applied to evaluate backwater profiles for the probable maximum flood.

\begin{tabular}{|ll}
\hline 15. SUBJECT TERMS & Hydrodynamic \\
Bridge pier & Stage \\
Floodway & Two-dimensional \\
\hline
\end{tabular}

16. SECURITY CLASSIFICATION OF:

\begin{tabular}{l|c}
\hline a. REPORT & b. ABSTRACT \\
UNCLASSIFIED & UNCLASSIFIED \\
\hline
\end{tabular}

c. THIS PAGE

UNCLASSIFIED 17. LIMITATION
OF ABSTRACT
18. NUMBER
OF PAGES

44 19a. NAME OF RESPONSIBLE PERSON

19b. TELEPHONE NUMBER (include area code) 